\title{
Round Barrows and Dykes as Landscape Metaphors
}

\author{
Christopher Tilley
}

This article outlines the results of phenomenological research on the significance of landscape features, in particular ridges and coombe (dry valley) systems, in relation to the locations of Bronze Age round barrows and late Bronze Agelearly Iron Age crossridge and spur dykes constructed along a chalk ridge in central southern England. It considers the locations of these monuments in a holistic manner and argues that together the round barrows, and then subsequently the dykes, network or draw together very different aspects of the topography in narratives about life and death. The round barrows differentially reference the significance of these places metaphorically through a combination of their specific locations. By contrast, the monumental courses of the dykes physically impose themselves on, or objectify the significance of, the same landscape features, but in a radically different manner indicating both continuity and difference in the historical significance of place.

Landscapes are known intimately through day-today bodily encounter. They form an essential focus for group identity in relation to locality, and a collective expression of normative and interpersonal beliefs and values. To truly understand the significance of landscape, either in the past or in the present, requires an insider's knowledge of the significance of place in relation to the wider landscape which is precisely that - to be inside it, to identify onseself with it, to belong to it, to attribute value and significance to it, to understand relations and interconnections. Place, landscape, social and personal identity and experience are all intertwined. Feeling, emotion and significance are thus both embedded and embodied in relation to places and the manner in which they are experienced.

To understand and interpret at least some of this the archaeologist has to move from the 'outside' of place and landscape to be somewhere on the 'inside' and this seems to be best achieved through a phenomenological study - through familiarizing ourselves with the landscapes and places which we seek to understand through personal bodily experience and encounter, exploring the world through our bodies (Tilley 1994; 1999; 2004).

The study that follows is a detailed account of round barrows, places of burial and ceremonial constructed during the earlier Bronze Age (see Woodward 2000 for a recent review), and dykes, long linear earthworks consisting of a single bank and ditch or double banks with an internal ditch, cutting across hill spurs or ridges and dated to the Late Bronze Age or early Iron Age. The interpretative framework put forward could never have arisen without being born out of this personal physical experience and knowledge of place. It would be absolutely impossible just using a map. The landscape itself, and the barrows and dykes in it, exerted their own agency, or effects, on my experience and perception of them. I would like to claim that they both influenced and constrained what it became possible to write. In this sense they themselves are the mute co-authors of this article.

I want to argue that both round barrows and dykes acted as material metaphors for the wider landscape. In other words their locations were significant, not just in themselves, as markers of specific places in the landscape. They were also 


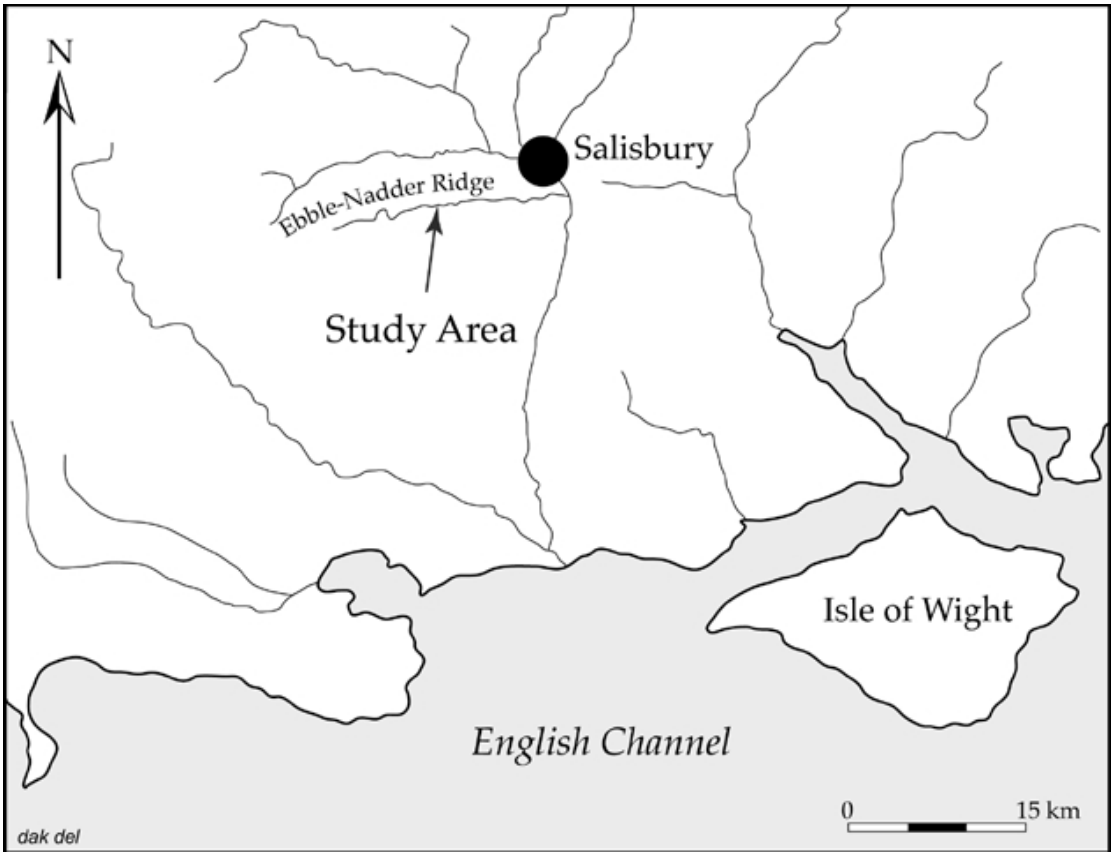

Figure 1. Location of the Ebble-Nadder ridge in southwest Wiltshire. Study area refers to Figure 4.

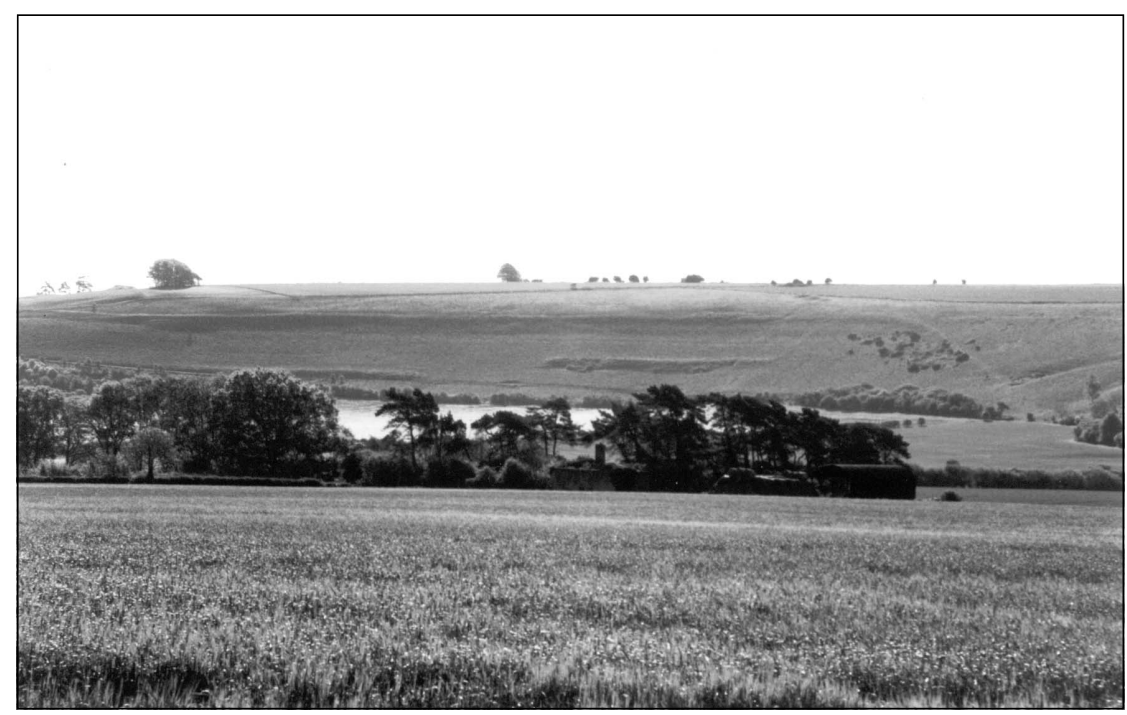

Figure 2. The northern escarpment edge of the Ebble-Nadder ridge at its eastern end, known as Hoop Side, seen from the north. The Punch Bowl Barrow (Fig. 4:23) is marked by the clump of trees on the ridge top to the left of the picture. Immediately below it, dykes $A$ and $B$ cut across Burcombe Spur. The tree on the skyline in the centre of the photo marks the position of the Burcombe summit barrow (Fig. 4:22). Between these two barrows, on the scarp edge, barrows 19-21 (see Fig. 4) are located.

significant in the manner in which they were dialectically related both to their immediate and more dis- tant surroundings in the landscape as a whole.

\section{The Ebble-Nadder ridge}

The Ebble-Nadder ridge, forming the northern edge of Cranborne Chase in southwest Wiltshire, is a dramatic stretch of chalk downland bounded by the river Nadder and the undulating greensands and clays of the Vale of Wardour to the north and the more narrow and incised valley of the river Ebble to the south (Fig. 1). It forms a bold scarp on its northern side, an unbroken barrier extending from Hoop Side Hill $(181 \mathrm{~m})$ in the east to Whitesheet Hill in the west (242 m), a distance of $14 \mathrm{~km}$ (Fig. 2). The ridge gradually descends in height from west to east along its length and the land dips gently away from the ridge top to the south and the Ebble valley. The crest of the entire ridge is narrow, generally only about 180 to $270 \mathrm{~m}$ wide. Along it, usually just to the south of the very highest ground, runs the former Shaftesbury to Salisbury turnpike road. Arable land is now characteristic along the ridge top but with the steep scarp slopes remaining unploughed and under pasture. Below the northern scarps, small woods or copses, sometimes called Ivers, still remain. The southern side of the ridge top is broken up with a series of steepsided coombes (dry river valleys) running into it from the south, dissecting the otherwise fairly gentle slopes running down to the Ebble valley (Fig. 3). Altogether about 50 round barrows and sixteen cross-ridge and spur dykes are recorded along the ridge as a whole.

In the study below I will discuss in detail the locations of twenty-four round barrows and four dykes towards the eastern end of 
this great ridge. Here (see Fig. 4) a reticulated series of branching coombes cut deeply into the ridge from the south. Three V-shaped coombes with narrow flat bottoms, only $5-10 \mathrm{~m}$ or so wide, meander through the chalk approximately north-south. Those to the west and east fork at their terminal ends. The central coombe is more linear and regular in form, lacking a bifurcated end, and cuts furthest into the ridge to the north. There is thus a rough symmetry in their form with the forking coombes to the east and west of the central simpler straight coombe. The deepest and widest of these coombes is that to the west which, from its southern end, at first runs approximately west-east before swinging round to the northwest and then to the north. These three coombes run roughly parallel to each other, north-south, for 1.3 $\mathrm{km}$ before joining where the coombe bottom becomes comparatively wide (see Figs. 8 \& 9), about $200 \mathrm{~m}$ across. Here it runs east-west before curving round to run north-south and then northwest to southeast where another narrow coombe joins the system before it eventually opens out into the Ebble valley. These three parallel coombes are unique along the Ebble-Nadder ridge, a fact which gives them an added significance. Elsewhere along the ridge the coombes are more widely separated and usually constitute a single irregular series of bifurcating and meandering dry valleys.

The walking distance, following the overall course of the coombe system, between the river Ebble and their terminal ends is about $5.6 \mathrm{~km}$. The journey from

Figure 4. The distribution of round barrows and dykes at the eastern end of the Ebble-Nadder ridge in relation to topographic features.

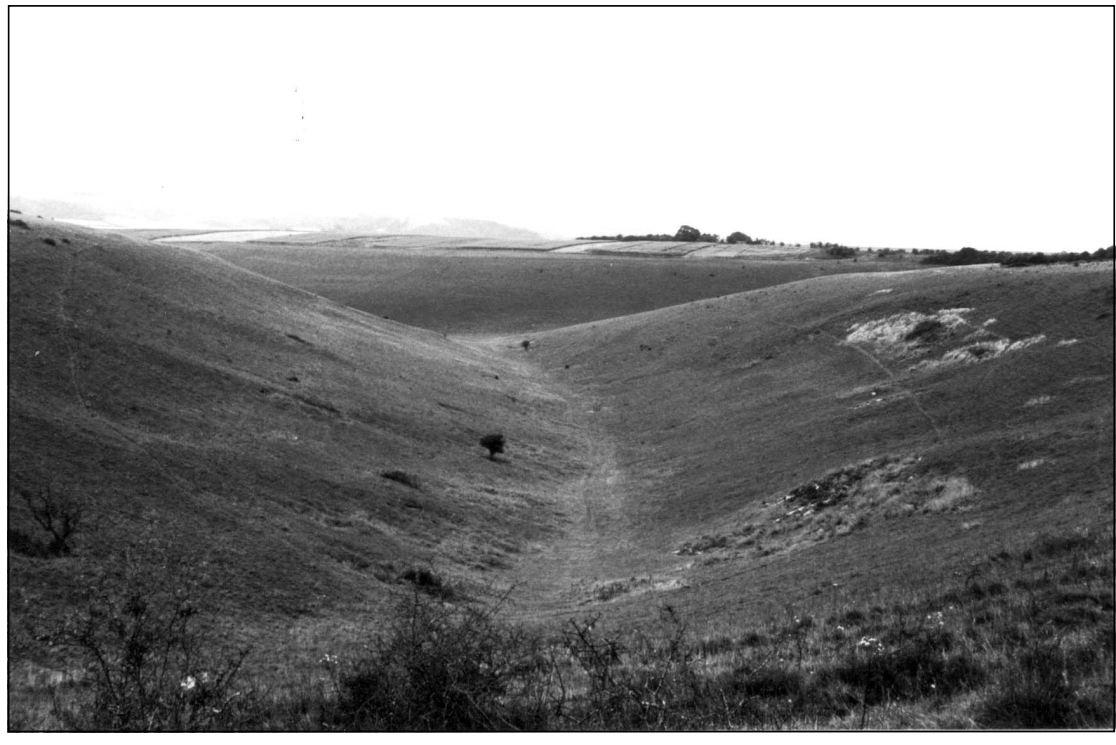

Figure 3. Typical deeply-incised coombe cutting into the Ebble-Nadder ridge from the south.

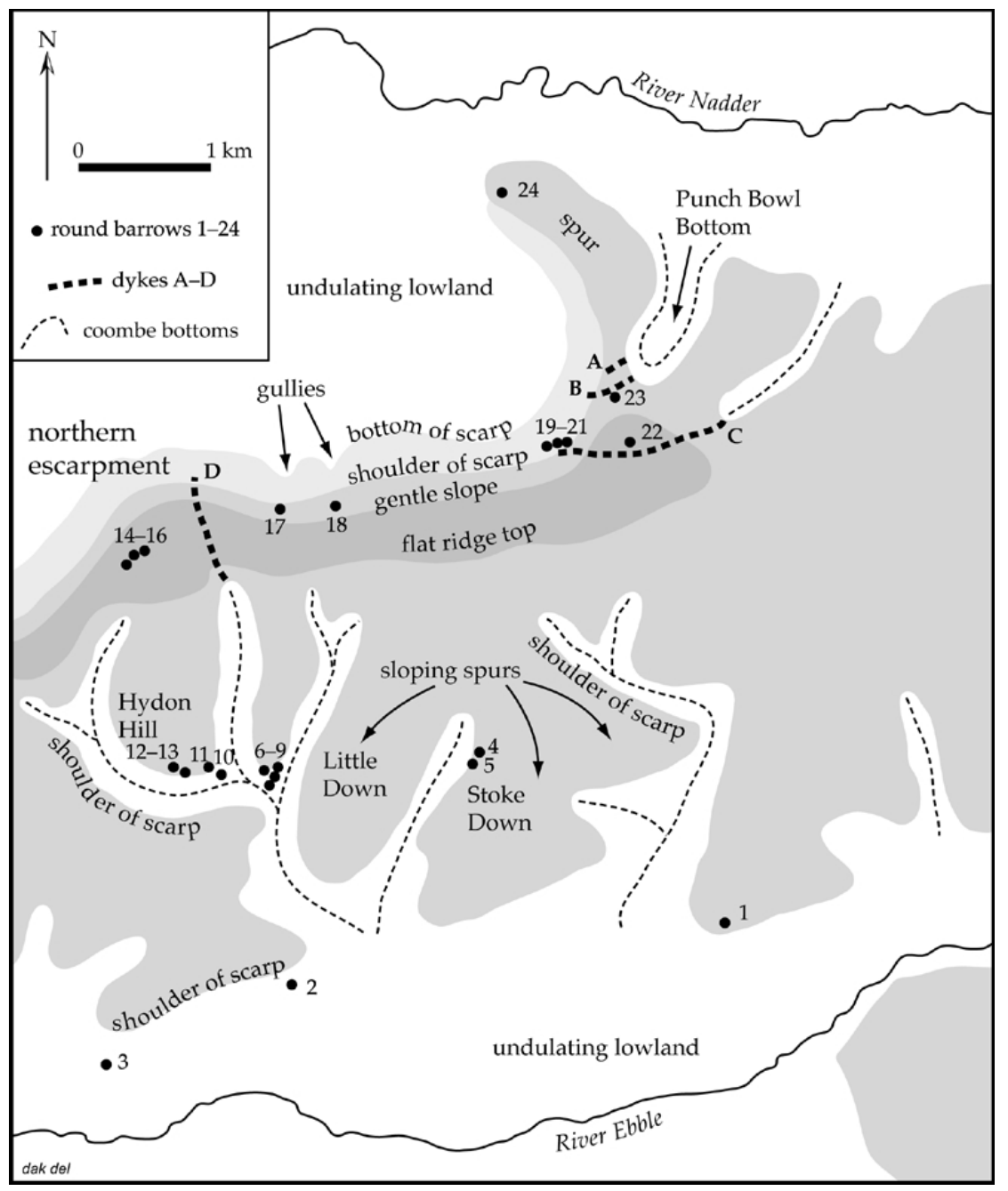




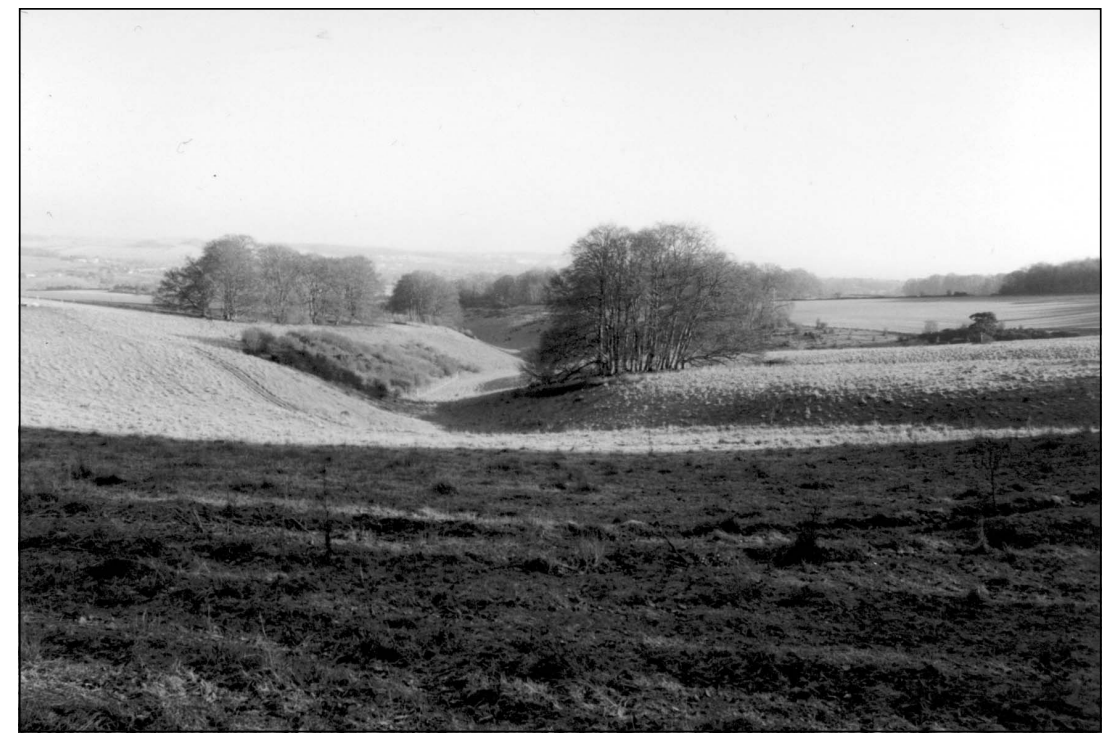

Figure 5. Looking northeast down the coombe which cuts into the northern side of the escarpment edge to the east of Punch Bowl Bottom from the probable eastern end of dyke $C$.

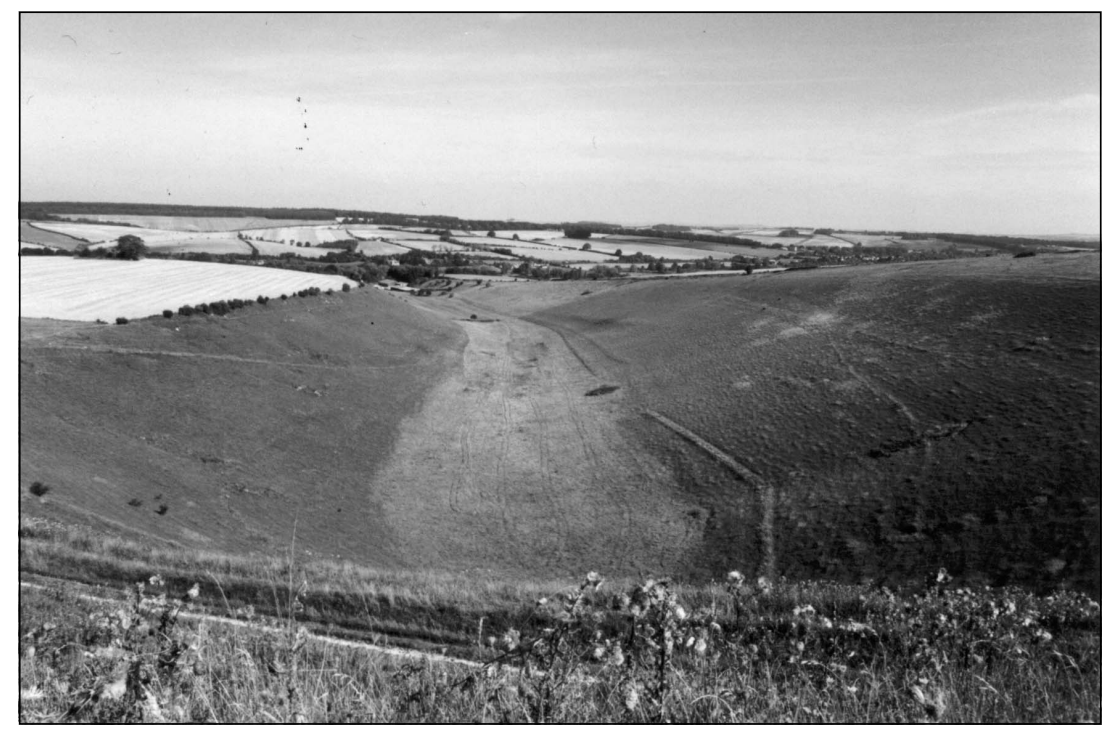

Figure 6. Punch Bowl Bottom seen from the eastern end of dyke B. (see Fig. 4). Both of these occur in the area under discussion, at the far eastern end, just before the ridge itself dips away to the east and is lost altogether. The most easterly coombe is rather shallowly incised and is V-shaped. It lacks any clearlydefined flat bottom and meanders into the ridge from the northeast (Fig. 5). Just $250 \mathrm{~m}$ to the west, Punch Bowl Bottom (Fig. 6) is utterly different and absolutely unique in form in a number of respects. It cuts into the ridge from the Nadder valley, at first running south and then swinging around to the southwest. It is bold, very steepsided, and has a comparatively wide tongue-shaped flat bottom which widens out, rather than narrowing, as is otherwise always the norm, towards the coombe end. It converges with a long spur running north out from the ridge. This leaves only a narrow sliver of high land between the coombe end and the northern escarpment edge to the west. This dramatic convergence of coombe, steep escarpment edge, and jutting spur is an elemental clash of distinctive topographic forms which are separated everywhere else along the ridge (see Figs. 4, 6 \& 15).

Overall, five topographically distinctive features of the landscape at the eastern end of the EbbleNadder ridge can be defined:

i. the reticulated and linked steepsided coombe systems with their steep scarp slopes to the south of the ridge top;

ii. the individual coombes cutting into the ridge at its eastern end to the north;

iii. the steep, unbroken and precipitous northern escarpment which runs approximately west-east before swinging round to the north, forming the spur above Burcombe at its eastern end. The continuous and bold line of this steep scarp slope is only broken by shallow, but nevertheless distinctive, gullies;

iv. gently sloping and slightly domed wide spurs running south from the ridge top; 
v. the narrow flat ridge top itself. These are shown on Figure 4.

\section{Round barrows in the landscape}

Approximately twenty-four round barrows are known from the eastern end of the Ebble-Nadder ridge. These are all round barrows of simple form and generally small in size, 7-15 $\mathrm{m}$ in diameter. Eight have traces of a surrounding ditch. Some have obviously been plundered, with pits in their tops. None have any known recorded artefacts or excavation records. Eleven, or nearly 50 per cent, have now been destroyed by ploughing and their location is only known from aerial photographs. In this section I describe the individual relationships of these barrows to the major topographic features of the landscape

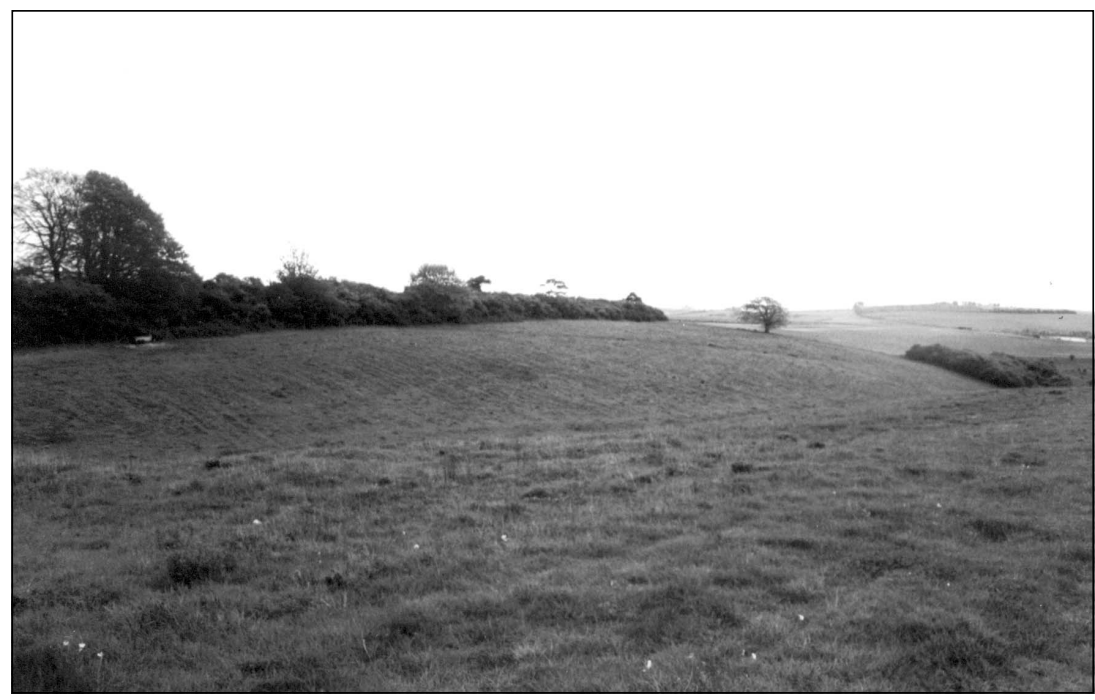

Figure 7. Location of barrows 4 and 5 seen from the northwest across the head of the coombe. The barrows are located in the hedge and tree line at the centre of the photo. End of coombe to left; to the right the coombe deepens and changes direction. noted above, basing this on observations taken from the barrows themselves, or the former barrow sites in the case of those destroyed.

\section{Bishopstone (Fig. 4:1)}

A barrow, now destroyed, was situated on the southern tip of a gentle spur sloping south. It was situated on flat ground on the eastern side of the spur top just above the point at which the land dips at first gently, then more steeply, south to the Ebble valley. From the barrow site there are surprisingly extensive views to the west and east along the Ebble valley. To the north the visual field reaches over $2 \mathrm{~km}$ to the ridge top and extends south for over $1 \mathrm{~km}$ to the hills marking the other side of the Ebble valley.

\section{Broad Chalke (Fig. 4:2-3)}

To the west, two further probable barrow sites (2-3) are recorded on the mid points of gentle southern slopes running down to the Ebble valley. That furthest west is only about $100 \mathrm{~m}$ north of a spring line on the eastern side of a coombe system running down into the Ebble valley. Views are extensive along the Ebble valley to the east and west, limited by rising ground to the north and across the valley to the south. The eastern barrow is on a gentle southeast slope again overlooking the Ebble valley with restricted views to the north. These barrow sites are not intervisible with each other as with that at Bishopstone.
Poor Patch, Stoke Down (Fig. 4:4-5 \& Fig. 7)

Two small adjoining barrows in a north-south alignment are situated above the shoulder of the scarp slope on gently sloping ground, dropping down to the west, about $400 \mathrm{~m}$ to the south of the head of a coombe which meanders south to join the valley linking the Hydon Hill and Little Down coombe systems. The bottom of the coombe is not visible from immediately below the barrows to the west, although one can look along the course of the coombe to its head to the north and along it for a short stretch to the south. Views to the east are very restricted by the gently rising ground of the spur top. To the west they are limited by another rising spur. No other barrows are visible.

Hydon Hill/Little Down (Figs. 4:6-13; Figs. 8 \& 9) A dispersed group of eight round barrows are located around the area at which three coombes merge. All are relatively small, between 7 and $15 \mathrm{~m}$ in diameter and less than $0.8 \mathrm{~m}$ high. At least four appear to have had a surrounding ditch. Four barrows cluster at each of the southern ends of the two spurs, Hydon Hill and Little Down, separating the three coombes. In each case the southernmost barrow is located low down the scarp slope, falling away to the coombe bottom. One of these, barrow 6 , is located exceptionally low down in the landscape, only about $30 \mathrm{~m}$ to the north of the very bottom of the coombe system. Three others, 7, 8 and 9, less than $100 \mathrm{~m}$ to its north, 


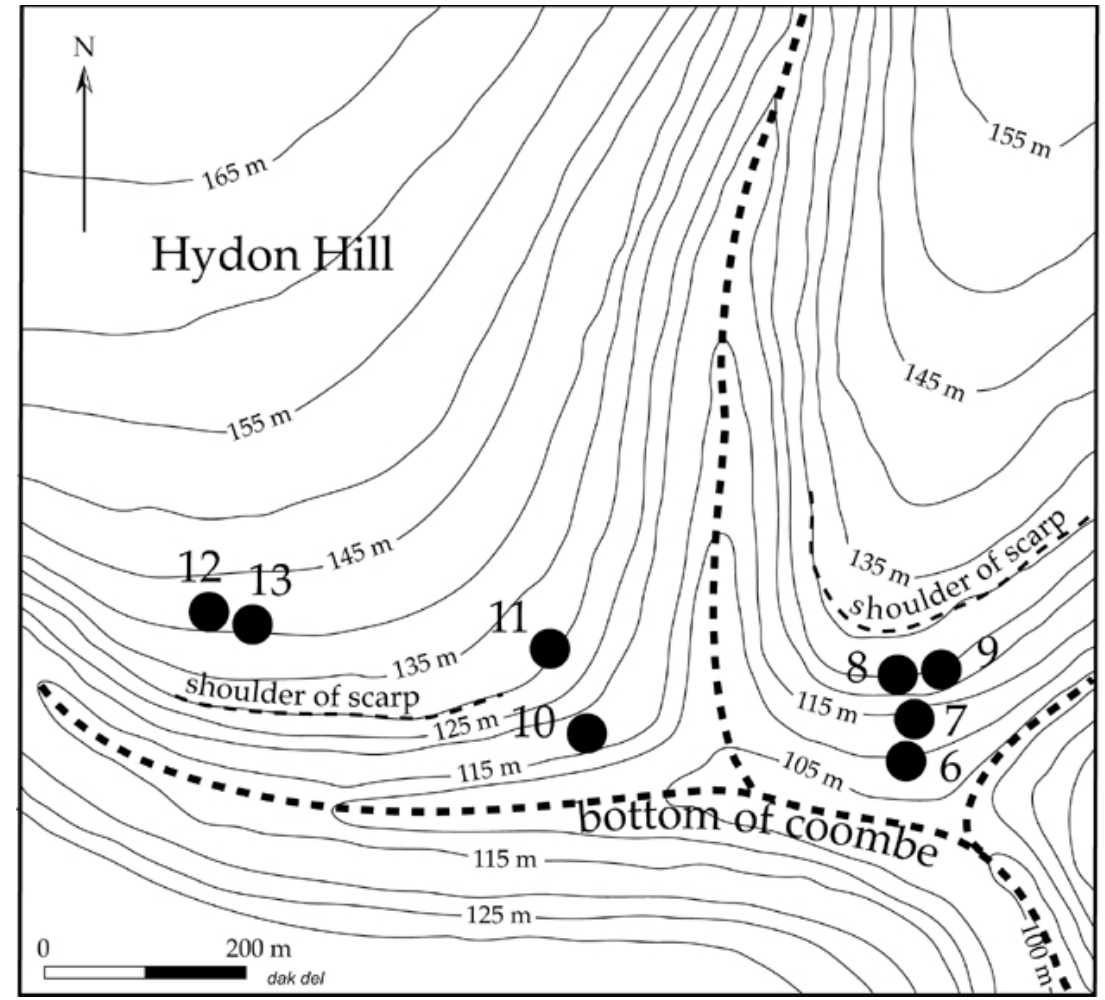

Figure 8. Location map of barrows 6-13 at the point at which three coombes join. Barrows 7 and 11 are destroyed.

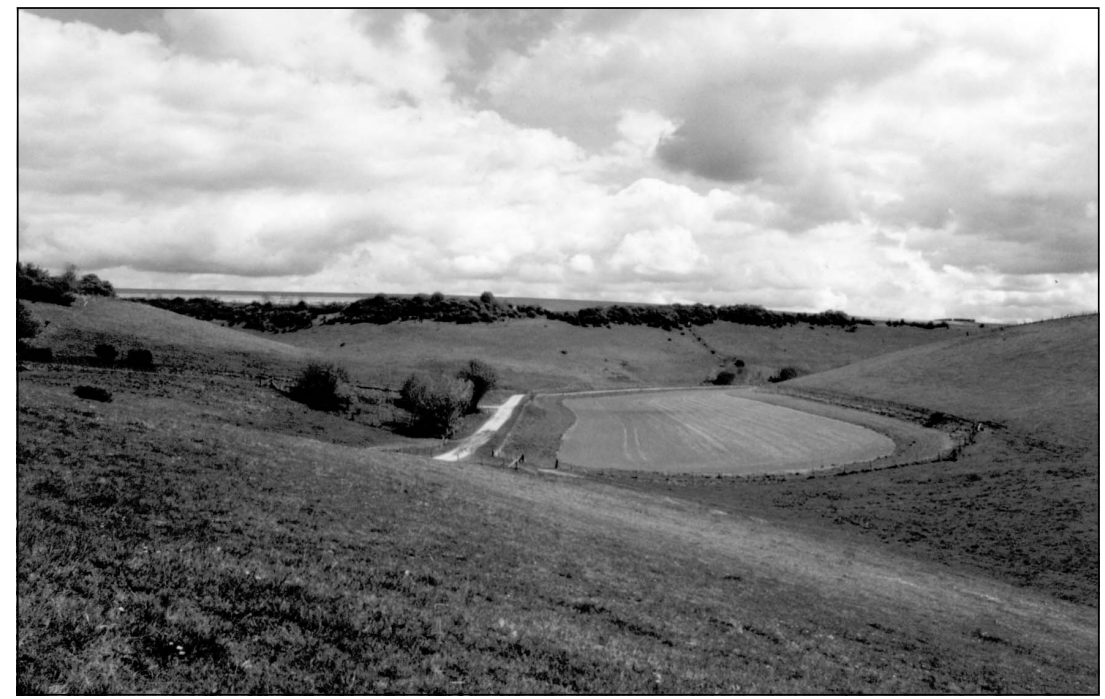

Figure 9. Photo taken from the top of barrow 10 looking east along the coombe bottom. The spur end on which barrows 6-9 are located is to the left of the photo above the white track. On either side of this spur, narrow coombes conjoin to form a wider system which sweeps around to the south. invisible from the spur top to the north, but effectively skylined and prominent from the coombe bottom below to the south. From all these four barrows, which are intervisible, one can look down to the bottom of the coombe to the south, but any view to the north is blocked out by the steep slope. They were thus positioned so as to be seen from the bottom of the coombe and occur on the terminal point of a narrow spur less than $200 \mathrm{~m}$ wide separating parallel coombes (Fig. 9). Because of the manner in which the coombes curve, meander and branch it is impossible either to see up to the end of any of them or beyond their terminal points up to the top of the chalk ridge to the north (Fig. 10).

The western group of barrows are structured slightly differently in the landscape. Barrow 10 is intervisible with barrows 6-9, but among the others closer to it, it can only be seen from barrow 11 situated about $100 \mathrm{~m}$ to its north exactly on the shoulder of the scarp. Barrows 12 and 13 are situated higher up the slope above the shoulder of the scarp on the far southern end of the spur of Hydon hill and are invisible. Although barrow 10 is situated only $250 \mathrm{~m}$ due west of barrow 6 it is situated far higher up the slope of its respective spur, approximately half-way up the slope from the base of the coombe to the scarp shoulder above. This is the only barrow in the western group (nos. 10-13) that can be seen from the coombe bottom below to the south or from which the coombe bottom itself is visible immediately below it.

The barrows are thus structured in relation to the landscape in the following way:

1. Two groups of four barrows are located at the extreme southern are situated on much more steeply-sloping ground below the shoulder of the scarp, thus making them ends of south-running spurs around the point at which three parallel coombe systems converge. 
All have restricted views to the north because of rising ground.

2. The barrow lowest down in the landscape is situated almost at the bottom of the coombe furthest to the east. The highest two barrows are situated above the scarp shoulder furthest to the west and from them the bottom of the coombe to the south below is invisible.

3. The other five barrows are situated in intermediate positions as follows: half-way up the scarp slope ( two barrows, one in each group of four), just below the scarp shoulder (two barrows in the eastern group) and on the scarp shoulder (one barrow in the western group).

4. Barrows 6 and 10, although opposite each other on an eastwest axis, mark very different points of transition between the coombe bottom and the top of the scarp slope: near the very bottom and half-way up the slope.

5. Considered together, the eight barrows mark every transitional space between the coombe bottoms and the top of the spurs:

a) virtually, but not quite at the bottom of the coombe (barrow 6);

b) half-way up the scarp slope (barrows 7 \& 10);

c) just below the shoulder of the scarp (barrows 8 \& 9);

d) on the shoulder of the scarp (barrow 11);

e) above the shoulder of the scarp (barrows 12 \& 13).

Walking between the barrows, from east to west and from the lowest to the highest, one moves from the coombe bottom to mid-points on the scarp slope to the shoulder of the scarp to the higher flat spur tops beyond. Taken together, and in relationship to each other, the barrows thus mark all the significant transition points in the landscape between the coombe bottom and the ridge spurs to the north and beyond.

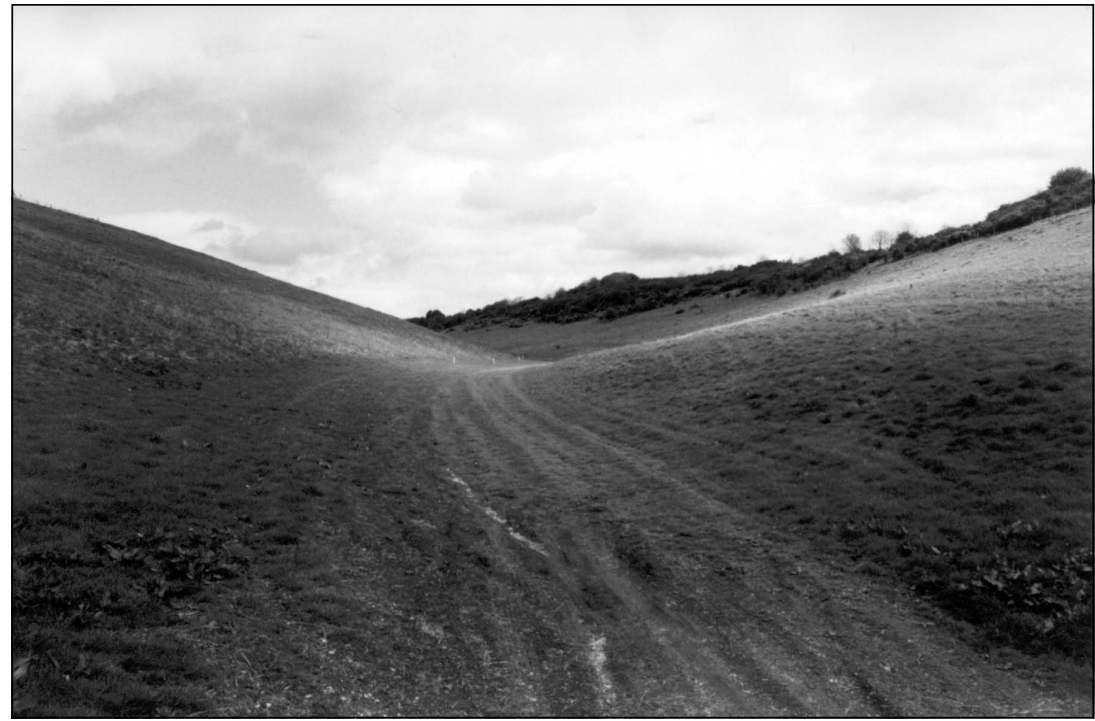

Figure 10. Looking up the most easterly of the three converging coombes in the Hydon Hill/Little Down area (see Fig. 4.)

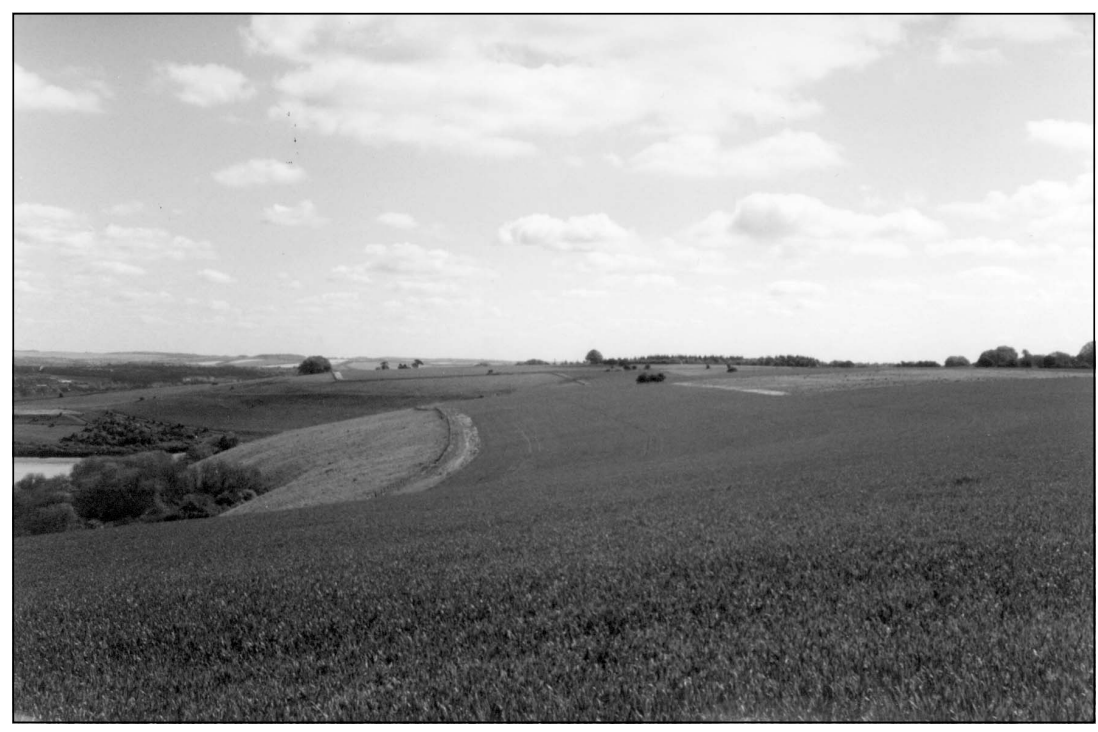

Figure 11. Looking east across the flat ridge top. Barrows 17 and 18 were located on the slope above the scarp edge in the centre of the photo. Barrow 23 marked by a clump of trees is located on the distant spur visible to the left of the photo. Barrow 22 is marked by the tallest tree on the skyline at the eastern end of the ridge in the centre of the photo.

Burcombe ridge top barrows (Fig. 4:14-16, 22; Fig. 11) Stretched out along the ridge top there are a further six barrows. Four of these are situated on the very highest points to the east and the west, the distance between them being $2.5 \mathrm{~km}$. These barrows on the flat ridge summit, all but one now destroyed, would all have been intervisible along the ridge top. Bar- 


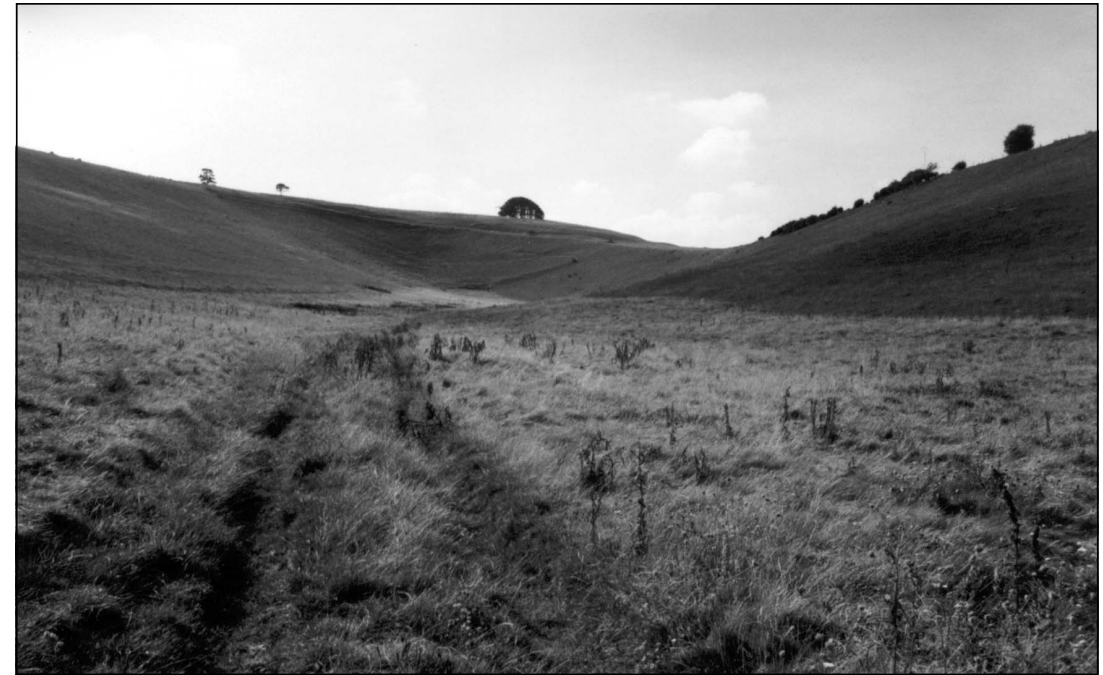

Figure 12. Looking along the course of Punch Bowl Bottom to barrow 23 marked by the clump of trees on the skyline. Dykes A and B run to the edge of the steep scarp slope below the barrow at the end of the coombe.

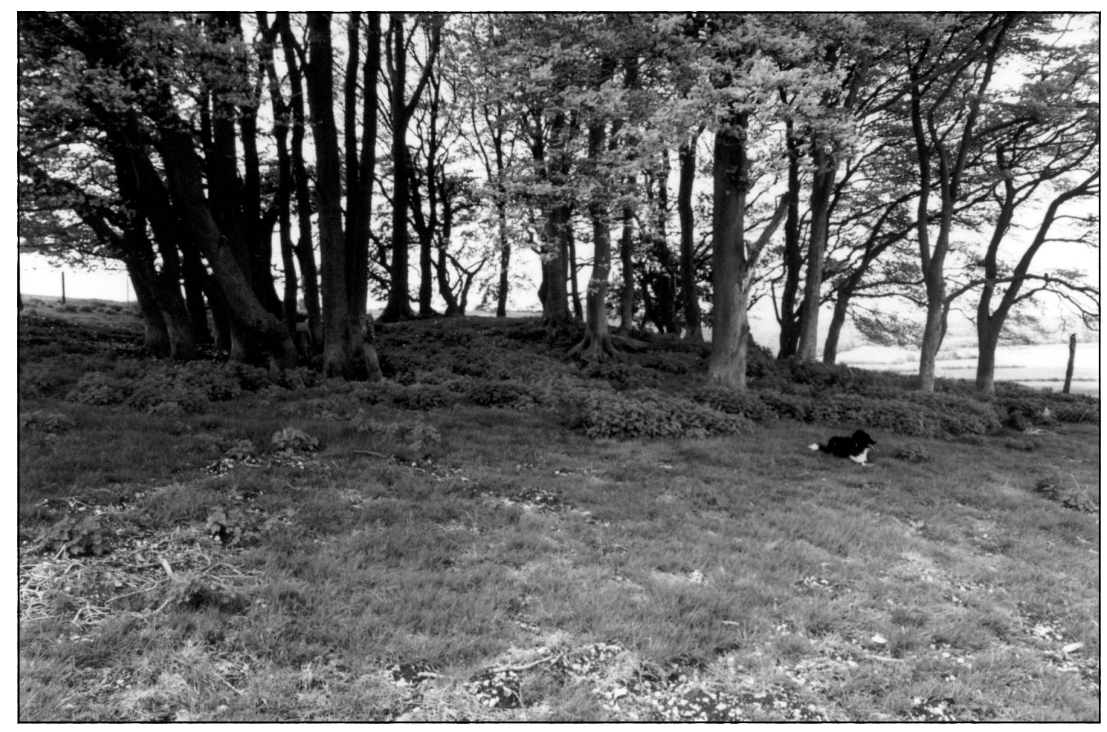

Figure 13. The round barrow marking the head of Punch Bowl Bottom, the largest barrow at the eastern end of the Ebble-Nadder ridge.

rows 14-16 mark the limits of the visual field looking west along the ridge top from barrow 22, while barrow 22 similarly marks the limits of the field of vision looking east from barrows 14-16 (Fig. 11). None of the coombes cutting into the ridge from the south or north are visible from them. Similarly the presence of a steep escarpment edge to the north is hidden from the barrow locations but views are extensive in this direction.
Burcombe Ivers barrows (Fig. 4:1718; Fig. 11)

Two further barrows, now destroyed, were also situated near to the top of the ridge but below the flat ridge summit. They are on gently sloping ground a little distance below it, but well above the sharp shoulder of the scarp. Each barrow is situated near to the south of a distinct gully in the northern escarpment edge that runs due west-east at this point. Views to the south are restricted by the rising ridge top. They are extensive off the ridge to the north. The scarp slope beyond to the north can be seen from these barrow sites but not its bottom immediately below them. To the west the visual field is again limited by the rising land of the ridge top and the barrows would not be intervisible with the summit barrows (nos. 14-16) in this direction. These two barrows are situated in a transitional zone between the flat ridge summit and the shoulder of the scarp slope. They, and the other ridge top barrows, are all highly visible from off the ridge top in the Nadder valley below to the north.

\section{Hoop Side (Fig. 4:19-21)}

Here a unique cluster of three adjoining barrows is situated just below the shoulder of the scarp where it drops away precipitously to the north. They are aligned in a staggered west-east row on sloping ground. There is a distinct gradation in size. The largest and highest barrow, about $16 \mathrm{~m}$ in diameter and $2.6 \mathrm{~m} \mathrm{high}$, is situated at the eastern end of the group highest up the slope. The smallest, 1.3 $\mathrm{m}$ high and $10 \mathrm{~m}$ in diameter, is situated lowest down the slope at the western end. Visibility to the south is very restricted by the rising land of the ridge top. To the north it is extensive off the ridge, to the east it is limited again by rising ground. To the west it extends to the Burcombe summit top barrows (nos. 14-16) that would be skylined in this 
direction. The three Hoop Side barrows are situated at the point of the escarpment edge just where it begins to swing round to the north to form the spur cut into by the Punch Bowl coombe to the east. From the two westerly barrows the base of the northern scarp slope immediately below is visible. From the third, higher barrow to the east it is not. The barrow on the flat summit area (no. 22) only $400 \mathrm{~m}$ to the east is invisible. This contrasts with the view $2 \mathrm{~km}$ west to the summit barrows (nos. 14-16) which would have been visible in this direction. From the barrows the Burcombe Punch Bowl barrow (no. 23) is also visible $500 \mathrm{~m}$ away to the northeast and another on the end of the north-running spur below, $1.5 \mathrm{~km}$ to the north (no. 24).

Burcombe Punch Bowl (Fig. 2; Fig. 4:23; Figs. 12 \& 13)

This barrow is dramatically situated at the head of Burcombe Punch Bowl coombe. It is situated on land gently sloping to the south well above the shoulder of scarp slopes to the west and north. This is the largest and most impressive surviving barrow in the area, 18$20 \mathrm{~m}$ in diameter and $1.5 \mathrm{~m}$ high. From the barrow one can look down the lower part of the coombe. The base of the coombe immediately below the barrow, however, is concealed by the slope. The summit barrow just $300 \mathrm{~m}$ to the north (no. 22; see Figs. 2 \& 4) is hidden by rising ground while all those to the west along the ridge top are visible, as is the barrow marking the end of the spur below to the south (no. 24).

Burcombe Spur (Fig. 4:24; Fig. 14)

This barrow is situated on flat land on the far northern end of a spur on the western side before the land dips down sharply to the Nadder valley. From the barrow site (it is now destroyed) there are extensive views to the west and east along the Nadder valley,

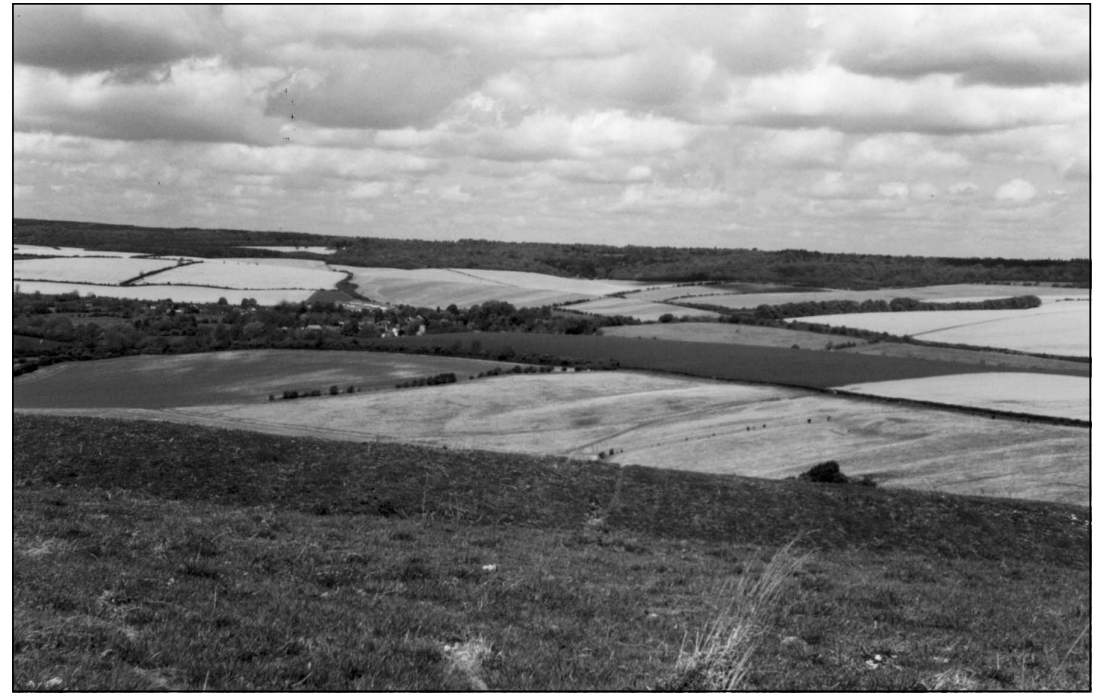

Figure 14. View over the northern spur at Burcombe at the eastern end of the Ebble-Nadder ridge. Barrow 24 is located towards its end in the middle of the photo. Part of spur dyke B is visible in the foreground.

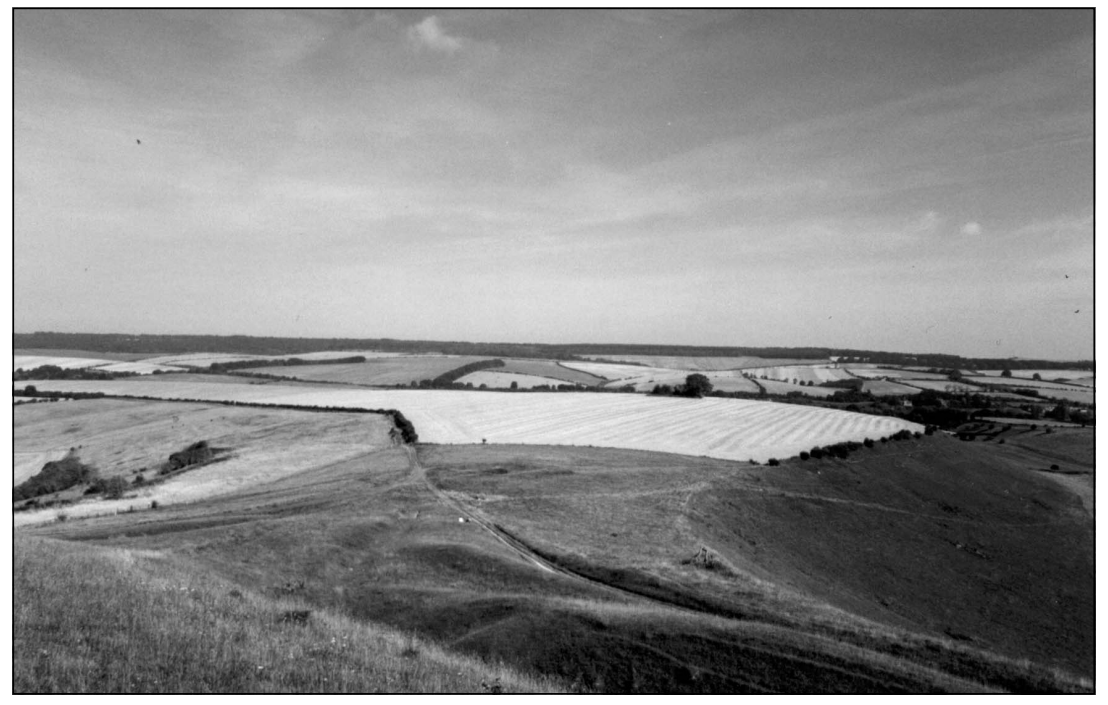

Figure 15. The narrowing of Burcombe Spur seen from spur dyke B. The edge of Punch Bowl Bottom is visible to the right of the photo and the upper part of the northern escarpment edge to the left.

to the north up to the top of the Grovely ridge beyond and south up the ridge top to the Punch Bowl barrow. To the southwest, the Burcombe summit top barrows (nos. 14-16) would have been skylined. This most northerly barrow and its relationship to the topography is almost a mirror image of the most southerly barrow (no. 1) on the low spur above Bishopstone. 


\section{Summary}

A number of points can be drawn out from these brief descriptions of the twenty-four barrow locations:

i. Barrows are situated in almost the full range of possible topographic locations in the landscape:

a) on flat summit areas of the ridge top $(N=4)$;

b) in transitional areas between the ridge top and the steep scarp slope to the north above gullies in the scarp edge $(N=2)$;

c) just below the shoulder of the northern escarpment edge at the point at which it changes direction $(N=3)$;

d) at the head of a distinctive coombe cutting into the scarp edge from the north $(N=1)$;

e) at the flat end of a northern spur low down in the landscape $(N=1)$;

f) at the flat end of southern spurs and slopes low down in the landscape $(N=3)$;

g) alongside and near to the head of a coombe running south $(N=2)$;

h) towards the southern ends of spurs where three parallel coombe systems running south join $(N=7)$.

i) almost at the bottom of a coombe where three parallel coombes join $(N=1)$. The only major topographic location from which barrows are absent is the middle of the spurs running south from the flat ridge top where the land slopes only gently and is relatively undifferentiated.

ii. Eleven of the twenty-four barrows are directly related to coombes (46 per cent) being located at or near to the head of the coombe or where coombes join. These are situated in a full range of possible locations in relation to scarp slopes: above the shoulder $(N=5)$, on the shoulder $(N=$ $1)$, just below the shoulder $(N=2)$, half-way down the slope $(N=2)$ and at the bottom of the slope ( $N$ $=1)$. The largest clustering of barrows occurs around the point at which coombes join. The largest barrow (no. 23) is sited at the head of a highly unusual and distinctive coombe cutting into the northern scarp edge, one of only two which do so.

iii. Seven of the barrows are related to changes in the character of the northern escarpment edge. Two mark a northern spur; two are related to gullies indenting its otherwise smooth profile; a unique cluster of three barrows, differentiated in size, mark the point at which the escarpment edge changes direction.

iv. Coombe bottoms immediately below the barrows are visible from only five of the eight barrows located south of Little Down/Hydon Hill (nos. $6-9,10)$. Otherwise, views are along and across the coombes from the barrow locations. Similarly the base of the northern escarpment edge is only visible from two barrows on Hoop Side (nos. 1920).

v. Some barrows, or pairs of barrows, have a visually discrete visual field in their own landscapes and other barrows are not visible from them. These are located along the coombes and the Ebble valley to the south. Barrows along the flat ridge top are by contrast visible for long distances along it but nearby barrows may be invisible while more distant ones are prominent and skylined. Only four of the barrows, all located on flat summit areas of the ridge top, seem to be located for maximum visibility along it. Six others along the ridge top seem to be sited for maximum visibility from off the ridge top, from the lowlands of the Nadder valley to the north. None of the barrows related to the southern coombes are intervisible with those along the ridge top to the north. In general, barrow intervisibility does not appear to be so important in relation to the siting of most as their relationship to highly localized topographic features of the landscape.

\section{Cross-ridge and spur dykes in the landscape}

No other prehistoric monuments or settlements are known along the eastern end of the Ebble-Nadder ridge apart from spur dykes and cross-ridge dykes which almost certainly began to be constructed here towards the end of the Bronze Age and into the early Iron Age (Fowler 1964). Two spur dykes and two cross-ridge dykes are known. I discuss each in turn and consider their relationship to both the earlier Bronze Age barrows and the wider landscape.

Burcombe (Fig. 4:A-C; Figs. 2, 5, 6 \& 14)

The first two dykes at the eastern end of the ridge run parallel to each other only $58 \mathrm{~m}$ apart, cutting across a low spur projecting out from the northern escarpment. Both are univallate with a single bank and ditch. The northern dyke is $64 \mathrm{~m}$ long with a 1 $\mathrm{m}$-high bank on the northern downhill side. The southern dyke, only about $30 \mathrm{~m}$ south of barrow 23 , is $160 \mathrm{~m}$ long and similarly has a single bank situated on the downhill side of the ditch. The dykes are situated on the mid point of a fairly gentle slope with the land rising above them. The shorter northern dyke is almost straight, terminating at its west- 
ern and eastern ends at the lip of much steeper slopes cut into by trackways and hollow ways. The southern dyke is markedly more curved and terminates much further down the lip of the slope at its western end.

The spur that the dykes cut across to the north is a well-defined and prominent landscape feature on which barrow 23 was sited. The spur below the barrow narrows at first, hence the much shorter length of the northern dyke, before widening out and flattening to form a low plateau to the south of the river Nadder (Figs. 14 \& 15). Both dykes terminate above the head of Punch Bowl Bottom at their eastern ends. From the eastern end of the southern dyke, which terminates just below the shoulder of the scarp running down into the coombe, the base of the coombe immediately below is visible (Fig. 6). The northern dyke ends further up the slope and the base of the coombe immediately below it is not visible from its end.

The eastern ends of both dykes are visible along almost the entire length of the coombe from where it begins just to the south of the river Nadder, and they appear to have been positioned so as to be seen in the distance while moving along the course of the coombe towards them. The southern dyke runs down to the very head of the coombe, so as to give an impression of being a natural continuation of it, whereas the northern dyke is positioned to terminate on the western (right) side of it. Both dykes link the head of the coombe with the escarpment edge to the west. From their western terminals one looks out across the plain below and along the impressive and unbroken line of the northern escarpment. From the western end of the southern dyke one can look down to the base of the escarpment below. This is not the case from the northern dyke which terminates higher up the slope.

About $300 \mathrm{~m}$ to the south of these two crossdykes there was probably a third, much longer bivallate dyke with two banks flanking a medial ditch running west-east for about $750 \mathrm{~m}$ up and across the crest of the ridge (Fig. 4:C). This earthwork was marked by Colt Hoare (1812) on his Station VIII map, but he did not describe it. The western end began on or near to the shoulder of the scarp but does not appear to have run down it just to the south of barrows 19-21. There is no trace of this on the ground now but Fowler was able to note its presence in the early 1960s (Fowler 1964, 54). It then ran across the ridge summit just to the south of another round barrow (Fig. 4:22) on the highest point. It then descended, turning somewhat to the north to termi- nate at the head of a shallow meandering coombe cutting into the scarp adjacent to Punch Bowl Bottom, to which Burcombe A and B are linked at their eastern ends. Here there are slight visible traces in woodland which may be the remains of this dyke. The two adjacent coombes are not intervisible, neither are the three cross-dykes except at their western ends. As already noted the two coombes are markedly different in form. The southern end of the eastern coombe, into which Burcombe dyke $\mathrm{C}$ probably ran, narrows effectively to the dimensions of a dyke itself so that the eastern end of Burcombe $C$ would create the impression of the coombe itself continuing on and out of sight across the hill top to the west. In this case the experiential effect of the dyke simply extended the coombe onwards up and across the slope (Fig. 5).

\section{Compton Hut (Fig. 4:D)}

This cross-dyke is shown by Colt Hoare (Station VIII map) as running in a meandering line between the head of Hut Bottom Coombe to the south (the central coombe in the parallel system of three described above) and the escarpment edge to the north. Today it is obliterated apart from a short length on the northern scarp where it runs down into Burcombe Ivers wood. The preserved section is univallate with a bank on the eastern side although Sumner (1913, 63) records the dyke as being bivallate in form. The bank runs out and the ditch continues well down the steep escarpment beyond the point at which one can see the base below. The ditch line is virtually indistinguishable from a natural depression or gully in the escarpment edge. The precise relationship with the head of Hut Bottom Coombe cannot be verified but the latter at its northern end is shallow, straightsided and narrow. Again, as with Burcombe C, the terminal end of this coombe and its dimensions resemble a bivallate cross-dyke with a medial ditch between two flanking banks, and the dyke would have run down a gentle incline to join it.

\section{Topography and its metaphoric significance}

The clustering of many of the round barrows in relation to the coombes indicates the significance of these places. Other round barrows also seem to be related to significant points along the northern escarpment edge - places where it is indented by gullies or where it changes direction. The construction of the cross-ridge and spur dykes appears to involve both a continued recognition of the significance of these places and that of some of the earlier Bronze Age 
barrows. Both the cross-ridge and spur dykes link together coombes and escarpment edges. Significantly, it is the central coombe of the Hydon Hill/ Little Down system around the southern end of which the barrows cluster at the point at which these coombes join, that is later linked to the escarpment edge to the north by the Compton Hut dyke D. It effectively continues the line of the coombe up and over the ridge and down the other side. Both of the only two coombes to cut into the northern escarpment edge are linked by dykes to the northern scarp. The course of the longer dyke, Burcombe $\mathrm{C}$, is obviously related to the location of pre-existing barrows in the landscape. Burcombe A and B cut across and mark out the same spur as the Punch Bowl barrow (no. 23). They run up to the coombe head, the importance of which is already marked by the barrow. The southern dyke situated only about 30 m north of the barrow continues down the precipitous scarp slopes leading down to the coombe bottom and the bottom of the escarpment edge, ending about where the bottom becomes visible below. The Compton Hut dyke D continues far down the precipitous slope of the northern scarp, well beyond the point at which the base of the scarp slope becomes visible. All the dykes link with the heads of coombes, either continuing their lines across the landscape or establishing a change of direction.

The characteristics of the chalk ridges and spurs and the coombes are strikingly different. These aspects of the chalk landscape together with the bold and indented escarpment edges give it its special qualities and character. Some of these contrasts are summarized below:

$\begin{array}{ll}\text { Ridge tops } & \text { Coombes } \\ \text { Wide views } & \text { Restricted views } \\ \text { Exterior } & \text { Interior } \\ \text { Windswept } & \text { Sheltered } \\ \text { Light } & \text { Shade } \\ \text { Dry } & \text { Wet } \\ \text { Treeless } & \text { Wooded } \\ \text { Looking down } & \text { Looking up } \\ \text { Visible } & \text { Secret/Hidden } \\ \text { Sound dulled } & \text { Sound amplified (echoes) }\end{array}$

The interiorized worlds of the coombes, each with their own individual qualities and character, are utterly different from the ridge tops and spurs that separate the coombes. The coombes wend and wind their way, join and bifurcate, open out and close in on themselves as they pass through the chalk. They have their own microtopographies, climate and veg- etation. They are hidden places, only visible at all from short distances away. All are invisible from central areas of the ridge and spur tops. These are, by contrast, relatively undifferentiated and uniform in character. It is only the escarpment edge that differentiates different parts of the ridge tops. The coombes amplify sound, have different qualities of light and shade. They invite one to follow and explore their courses, both dividing the landscape and establishing different natural paths of movement up and through it. The world of the ridge top is, by contrast, a big, wide and open landscape, a macroworld of the extensive vista as opposed to the small enfolded world of the coombe. Atmospheric effects and temperature inversions may fill the coombes with mist and cloud or alternatively blanket the ridge tops above. When the mists fill the coombes they are magically transformed into lakes. In exceptionally wet periods, water may begin to appear in the base of the coombes only to sink away again after a few hours or days.

Some of the barrows obviously mark out places of especial significance along the courses of the coombes - places where they join, or open out, and places where they end, perhaps conceived as doorways to a world below. These low, wet, mysterious and hidden incisions in the landscape with their inner depths, were probably associated with particular spirits, mythical forces and the underworld. Such places could be conceived as dangerous, hence from some barrow sites one looks across rather than down into the depths of the coombe. The association of other barrows with transitional places in the landscape on the way down to the coombe bottoms may be indicative metaphorically of the passage from life to death, the sky and the heavens to a watery underworld, hence their siting on the shoulder of slopes, or below the shoulder - half-way down the slope, for example. There is an important changing visual perspective in all this. From only a few barrows is the coombe bottom or the escarpment edge immediately below them visible: from them the depths can be seen. As the barrows are sited progressively higher up in the landscape this visual perspective of looking directly down into a different world below becomes successively diminished. Instead one has only partial views along or across coombe bottoms and escarpment edges. From the ridge-top summit barrows such a view of the landscape is entirely removed. Here one is only in contact with the sky. The relationship of other barrows to gullies and places where scarp slopes change direction indicates the symbolic significance of these aspects of the topog- 
raphy too as places of transition, perhaps again of a metaphoric journey from life to death, high to low. The barrows on the flat ridge-top summits, at the very highest points in the landscape, must obviously be associated with the sky and emphasize that height as well as watery depths was of great ritual significance.

It can thus be suggested that the entire barrow distribution, considered as a whole, networks or links together every distinctive topographic element in the landscape into a coherent whole with possible cosmological significance in terms of a life journey. They also obviously mark out the entire landscape and lay claim to it. The patterns of movement of people from coombe to ridge top to escarpment edge would always be marked out by these barrows. Now monuments to the dead can, of course, also be used to highlight significant differences between the status and power of those in the world of the living. Each coombe is unique in various ways. Some are strong and dramatic incisions in the landscape, others weak. Those who could symbolically control the 'strong' coombes and their spirit powers were able to enhance their authority in the world of the living. It is, perhaps, not so surprising therefore that the largest barrow (no. 23) is directly associated with the most prominent coombe, Punch Bowl Bottom, and is located at its head. Patterns of intervisibility between barrows might be related to social connections between particular lineage groups and coombes. A barrow could be linked to a particular coombe in such a way without having to be sited near to it.

The cross-ridge and spur-dykes, in earlier literature interpreted as defensive boundaries (e.g. Sumner 1913) or cattle-ways (e.g. Clay 1927) but more recently claimed to constitute territorial boundaries (e.g. Fowler 1964; Spratt 1989; Cunliffe 1990) may also directly relate to the contrasting symbolic and mythological significance of the coombes and the ridge tops, already marked out by the round barrows, but in a rather different manner.

Detailed study of dykes elsewhere along the western and central parts of the Ebble-Nadder ridge and along the nearby Ox-Drove ridge to the south of the Ebble valley (where twelve are known) has shown that in virtually all cases it seems to have been of great importance that an observer be able to see from the ends of the dykes down to the very base of the escarpment edge or to the bottom of the coombes immediately below. For this to be the case requires sometimes that the dyke descend over the shoulder of the escarpment and some way down the escarpment edge. Some, like Dyke D described above, re- sembling a slide, descend down the steep slope of the escarpment or coombe for anything up to $50 \mathrm{~m}$ or more in an exaggerated fashion, and far beyond the point at which the base first becomes visible below the dyke end. Others terminate more or less exactly at the point at which the base of the coombe or escarpment first becomes visible. All this suggests the importance of one's vision becoming directed downwards at the end of the dykes rather than simply out and across the wider landscape beyond.

A direct metaphorical relationship between coombes and dykes appears to be made explicit in the case of bivallate forms with a medial ditch, in that the forms of the dykes and the coombes closely resemble one another in many respects. This enables one to suggest that some of the cross-ridge dykes were considered to be continuations of the coombes and vice versa, and that the linkage created between dyke and coombe was of deep symbolic significance. The dykes as artifical coombes continued the lines of the coombes up into the sky and over the ridge top and down the northern scarps to the lowland bottoms beyond. In this respect, it is interesting to note the sinuous and meandering nature of many of the dykes and their often sudden change in direction and orientation. In this respect again they resemble the coombes. Straight dykes appear to be the exception rather than the rule. If the dykes were coombes in the sky, what implications does this have for our understanding of them?

It may have been that their function of linking together both the coombes and the lowlands was of equal or of greater importance to the manner in which they divided the ridges. Those dykes that cut across the ridge tops ipso facto divided them, but this cannot necessarily be assumed to be their primary purpose. The alternative argument is that they served to link and network together the topographies of coombes and lowlands. The dykes were expressions of sociocultural norms investing the landscape with meaning, a coding of space in relation to socially significant ridges, spurs and coombes. Their construction, use and meaning may have been part of a ritual practice seeking to maintain harmonious relationships with a complex pantheon of invisible beings and forces associated with wet places such as the coombes, river valleys and the lowlands, significant places for the deposition of votive deposits from the Bronze Age onwards (Bradley 1990; 2000). Thus the dykes were ritual works, perhaps processional routes or travelling ways, either in reality or in the imagination, between the coombes to the south and the lowlands to the north, from one coombe to an- 
other and from scarp to scarp. They were part of the manner in which cultural meanings in the landscape became materialized. As such, they may have formed part of a ritualized order of space, time and movement linked to the seasons, the significance of different cardinal directions, height and elevation, the juxtaposition of ridges and valleys, rivers, spurs and significant hills. Particular hills and spurs were clearly marked out and emphasized by the spur dykes while the crossridge dykes linked significant coombes, each with their own particular identities and associations, with the lowland. Yet other dykes joined one coombe to another. In sum, they connected important elements of the topography into a reticulated system improving on what nature had already done. They thus completed the link that 'nature', or the ancestral forces, had not made between the coombes and the lowlands beyond.

\section{Conclusions}

I have argued that the barrows were located to create connections and establish relationships both between themselves and other round barrows and to refer to, or connect up, significant 'natural' places in the landscape far beyond their specific location. In other words, the significance of the location of a barrow in one place was linked to that of another in a quite different place. The location of one barrow was understood in terms of that of another. They thus both marked specific places as meaningful and simultaneously acted as material metaphors for the wider landscape as a whole. They served to codify important topographic features of the landscape both in relation to themselves and through their links to other barrows in different places in it. Through the process of constructing round barrows in different places, people networked that landscape together into a coherent whole. Through these connections, metaphorically an individual barrow became the wider landscape and in turn the landscape was the barrow location. So people made themselves and their social relations and constructed their identities in relation to both the specificity of place and the totality of the wider landscape, conceived as a network of relationships between different places within it.

It was the relationships between the barrows and in turn their relationships with their landscape settings that empowered people to identify with the landscape as a whole rather than just to specific places (individual barrow locations) within it. The construction of dykes represented an alternative way of thinking-through, understanding and relating to landscape. Interconnections between different places in the landscape previously marked out as significant through the scattered individual locations of groups of round barrows now became physically joined together in the form of one large and continuous monument sweeping across it. Linkages that had previously been only conceptually implicit in the overall patterning of the individually very different locations of round barrows were now made explicit and objectified in a material form through the process of dyke construction. What had previously been a non-material resource in which the social and cosmological significance of the contrasts in the different landscape locations of barrows had to be connected together through experience and talk was now made materially explicit through the network of dykes inscribed across it.

While we have no direct evidence for Bronze Age settlement anywhere along the Ebble-Nadder ridge, early Iron Age enclosures along the central and western parts of the ridge directly associated with field systems and cross-dykes occur at Chiselbury and on Swallowcliffe Down (Clay 1925; Fowler 1964). This, together with Iron Age settlement evidence elsewhere at Fyfield Bavant (Clay 1924), may indicate a much more intensive and permanent pattern of occupation and use than is suggested by the earlier Bronze Age barrow distribution.

The construction of the dykes may therefore have related to an increasing social and political need to physically control and lay claim to the land itself and the material and symbolic resources that it provided. Their morphology and direct relationships to the coombes would effectively serve to naturalize them in the landscape. They might be perceived to be more a part of an order of nature, than an order of culture, and therefore had added social and political power when there was a desire to control the land. The argument here is that to do so involved physically networking different elements of the topography of the ridge together as opposed to dividing it up and erecting boundaries across it.

\section{Acknowledgements}

I am most grateful to two anonymous referees for critical comments on an earlier draft of this paper which have helped me to improve the argument and to Wayne Bennett for drawing up for publication the original line diagrams.

\section{Author biography}

Christopher Tilley is Professor of Anthropology at University College London. He is currently researching a 
trilogy of books on landscape phenomenology the first of which, The Materiality of Stone was published in 2004. Other publications include A Phenomenology of Landscape (1994), An Ethnography of the Neolithic (1996) and Metaphor and Material Culture (1999).

$$
\begin{array}{r}
\text { Christopher Tilley } \\
\text { University College London } \\
\text { Department of Anthropology } \\
\text { Gower Street } \\
\text { London } \\
\text { WC1E 6BT } \\
\text { UK } \\
\text { c.tilley@ucl.ac.uk }
\end{array}
$$

\section{Comments}

John C. Barrett, Department of Archaeology, University of Sheffield, Sheffield, S10 2TN, UK;

J.Barrett@sheffield.ac.uk.

The general claim Christopher Tilley makes is that for any occupant, places in the landscape make sense because they belong to a wider field of experience. Places must be located with reference to past experience and future expectations, and because both experience and expectation are themselves located elsewhere, places must be experienced as if they somehow bring together those absent locations. There are two obvious ways this may occur. First, the place may be conceived as a path along a journey, where its significance is as the point or moment that articulates the move from one region to another. Second, the place may be the location from whence a vista becomes available, the moment when all places fall into view and the totality of a landscape can be perceived. Thus places become meaningful to the occupant when they are recognized as metaphors for the wider landscape of experience. It follows, presumably, that such metaphors may extend the schemes of relationships from terrestrial experience to one that incorporates the movement of celestial bodies, the temporality of the seasons, and relations with the supernatural.

I would ask two questions: Is this characterization of the significance of place valid? How does this characterization enable us to understand the history of particular conditions? Tilley does not assess the validity of the general claim. Perhaps it seems reasonable either because it conforms to the ways we expect symbolic systems to work, structurally as a set of relationships, or because it simply works, providing us with a perspective on the material that we had not previously noticed. If this were the case then the general validity of the argument must be grounded upon its application, and this is where I begin to have problems. The phenomenological approach that we are offered rests upon the presumption that only by being 'inside' these landscapes can we can grasp the significance of the barrows and dykes along the Ebble-Nadder Ridge. To be inside the landscape appears to be a matter of walking and observing the ways monuments and topography relate. But to be inside these landscapes in the Bronze Age was to have been inside a different vegetation, was to have been inside half-built monuments, was to have been inside rights of access demarcated by familial and political obligations, and was to have been inside the habitus of bodily disciplines other than our own. I must conclude that historical knowledge is the knowledge of an outsider who sees in the specific lives of others something that they cannot share but nonetheless can claim to understand. I do not sense any indication of the practice of historical enquiry in Christopher Tilley's description. Historical conditions were not the contemplation of the world as it was, but were the recognition that what existed required that certain things be done. It was in the doing of what was deemed necessary that history was made and the monuments that we gaze upon today originated, were used, and then abandoned. If we do not understand this then I fail to see how we will ever begin to understand how a landscape that contained the monumental development of burial places for one generation could have given rise to a landscape necessarily demarcated by crossridge dykes for another.

Warren R. DeBoer, Department of Anthropology, Queens College, City University of New York, Flushing NY 11367, USA; WdeBoer@Qc1.Qc.Edu. I know next to nothing about the Bronze and Iron Ages and have never experienced the wind-swept summits nor mist-filled coombes of the Ebble-Nadder ridge. Ordinarily such limitations would be disqualifying, but let me try to get away with some freereined thoughts, tethered only by the information Tilley presents.

Tilley's Figure 4 sets the geological stage. The cast of barrows 1-24 dominates a multi-scene first act. After a prolonged intermission, the dykes A-D appear in what might be a second act or, perhaps, a separate play. Any unifying plot or theme is, at best, opaque. Choreography, however, is more detectable and, gratefully, also leads away from dramaturgical metaphor.

The accompanying matrix codes the 24 barrows in terms of intervisibility (v) as gleaned from Tilley's 
Matrix which codes the 24 barrows in terms of intervisibility.

\begin{tabular}{|c|c|c|c|c|c|c|c|c|c|c|c|c|c|c|c|c|c|c|c|c|c|c|c|c|c|}
\hline & 1 & 2 & 3 & 4 & 5 & 6 & 7 & 8 & 9 & 10 & 1 & 2 & 3 & 4 & 5 & 6 & 7 & 8 & 9 & 20 & 1 & 2 & 3 & 4 & $\Sigma$ \\
\hline 1 & & & & & & & & & & & & & & & & & & & & & & & & & 0 \\
\hline 2 & & & & & & & & & & & & & & & & & & & & & & & & & 0 \\
\hline 3 & & & & & & & & & & & & & & & & & & & & & & & & & 0 \\
\hline 4 & & & & & $\mathrm{~V}$ & & & & & & & & & & & & & & & & & & & & 1 \\
\hline 5 & & & & $\mathrm{~V}$ & & & & & & & & & & & & & & & & & & & & & 1 \\
\hline 6 & & & & & & & $\mathrm{~V}$ & $\mathrm{~V}$ & $\mathrm{~V}$ & $\mathrm{v}$ & & & & & & & & & & & & & & & 4 \\
\hline 7 & & & & & & $\mathrm{~V}$ & & $\mathrm{~V}$ & $\mathrm{~V}$ & $\mathrm{~V}$ & & & & & & & & & & & & & & & 4 \\
\hline 8 & & & & & & $\mathrm{~V}$ & $\mathrm{~V}$ & & $\mathrm{~V}$ & $\mathrm{~V}$ & & & & & & & & & & & & & & & 4 \\
\hline 9 & & & & & & $\mathrm{~V}$ & $\mathrm{~V}$ & $\mathrm{~V}$ & & $\mathrm{~V}$ & & & & & & & & & & & & & & & 4 \\
\hline 10 & & & & & & $\mathrm{~V}$ & $\mathrm{~V}$ & $\mathrm{~V}$ & $\mathrm{~V}$ & & $\mathrm{~V}$ & & & & & & & & & & & & & & 5 \\
\hline 1 & & & & & & & & & & $\mathrm{~V}$ & & & & & & & & & & & & & & & 1 \\
\hline 2 & & & & & & & & & & & & & $\mathrm{v}$ & & & & & & & & & & & & 1 \\
\hline 3 & & & & & & & & & & & & $\mathrm{~V}$ & & & & & & & & & & & & & 1 \\
\hline 4 & & & & & & & & & & & & & & & $\mathrm{~V}$ & $\mathrm{v}$ & & & $\mathrm{V}$ & $\mathrm{V}$ & $\mathrm{v}$ & $\mathrm{V}$ & $\mathrm{V}$ & $\mathrm{v}$ & 8 \\
\hline 5 & & & & & & & & & & & & & & $\mathrm{~V}$ & & $\mathrm{v}$ & & & $\mathrm{V}$ & $\mathrm{V}$ & $\mathrm{v}$ & $\mathrm{V}$ & $\mathrm{V}$ & $\mathrm{v}$ & 8 \\
\hline 6 & & & & & & & & & & & & & & $\mathrm{v}$ & $\mathrm{V}$ & & & & $\mathrm{V}$ & $\mathrm{V}$ & $\mathrm{v}$ & $\mathrm{V}$ & $\mathrm{V}$ & $\mathrm{v}$ & 8 \\
\hline 7 & & & & & & & & & & & & & & & & & & $\mathrm{~V}$ & & & & $\mathrm{~V}$ & & & 2 \\
\hline 8 & & & & & & & & & & & & & & T & & & $\mathrm{V}$ & & & & . & $\mathrm{V}$ & & & 2 \\
\hline 9 & & & & & & & & & & & & & & $\mathrm{v}$ & $\mathrm{v}$ & $\mathrm{V}$ & & & t & $\mathrm{V}$ & $\mathrm{V}$ & & $\mathrm{v}$ & $\mathrm{v}$ & 7 \\
\hline 20 & & & & & & & & & & & & & & $\mathrm{~V}$ & $\mathrm{~V}$ & $\mathrm{~V}$ & & & $\mathrm{~V}$ & & $\mathrm{~V}$ & & $\mathrm{v}$ & $\mathrm{v}$ & 7 \\
\hline 1 & & & & & & & & & & & & & & $\mathrm{~V}$ & $\mathrm{v}$ & $\mathrm{V}$ & & & $\mathrm{V}$ & & & & $\mathrm{V}$ & $\mathrm{v}$ & 6 \\
\hline 2 & & & & & & & & & & & & & & $\mathrm{~V}$ & $\mathrm{~V}$ & $\mathrm{v}$ & $\mathrm{v}$ & $\mathrm{V}$ & & & & & & & 5 \\
\hline 3 & & & & & & & & & & & & & & $\mathrm{~V}$ & $\mathrm{~V}$ & $\mathrm{v}$ & & & $\mathrm{V}$ & $\mathrm{V}$ & $\mathrm{V}$ & & & $\mathrm{v}$ & 7 \\
\hline 4 & & & & & & & & & & & & & & $\mathrm{~V}$ & $\mathrm{~V}$ & $\mathrm{~V}$ & & & $\mathrm{~V}$ & $\mathrm{~V}$ & $\mathrm{~V}$ & & $\mathrm{~V}$ & & 7 \\
\hline$\Sigma$ & 0 & 0 & 0 & 0 & 0 & 1 & 1 & 1 & 1 & 4 & 0 & 0 & 0 & 6 & 6 & 6 & 1 & 1 & 5 & 5 & 5 & 5 & 7 & 7 & \\
\hline
\end{tabular}

from the smaller coombe-based group of barrows $6-10$. In the follow-up table, barrows are sorted by whether they occur singly or in groups, by their elevation and location with respect to the eastwest trending ridge, and by their visibility status. The latter is partitioned into three components: inter-site visibility; intervisibility with a neighbouring coombe; and location affording vistas of distant lowlands. This rendering merely shows that salient, 'skyline' barrows tend to be located on high ground, while mounds nestled upon the edges or flanks of coombes have more local visual fields. This result, I would suggest, is unremarkable. The suite of sensory contrasts posited by Tilley is as much a topographic given as a metaphorical system.

Tilley notes that the lone barrow perched sentinel-like at the tip

\begin{tabular}{|c|c|c|c|c|}
\hline & \multicolumn{3}{|c|}{ VISIBILITY } \\
\hline SITES $(n=24)$ & SETTING & Inter-site & Coombe & Vista \\
\hline \multicolumn{5}{|l|}{ Isolates $(n=4)$} \\
\hline - & East/Low & 0 & - & 1 \\
\hline 2 & West/Low & 0 & - & 1 \\
\hline 3 & West/Low & 0 & - & 1 \\
\hline 24 & East/High & 7 & - & 1 \\
\hline \multicolumn{5}{|c|}{ Spaced Dyads $(n=4)$} \\
\hline $17-18$ & Center/Transition & 2 & - & 2 \\
\hline $22-23$ & East/High & 12 & 1 & 2 \\
\hline \multicolumn{5}{|l|}{ Clusters $(n=16)$} \\
\hline $4-5$ & Center/Transition & 0 & - & - \\
\hline $6-9$ & West?/Transition & 4 & 3 & - \\
\hline $10-13$ & West/Transition & 4 & 1 & - \\
\hline $14-16$ & West/High & 18 & - & 3 \\
\hline $19-21$ & East/High & 15 & - & 2 \\
\hline \multirow[t]{4}{*}{ TOTALS } & Low & 0 & 0 & 3 \\
\hline & Transition & 10 & 4 & 2 \\
\hline & High & 52 & 1 & 8 \\
\hline & All & 62 & 5 & 13 \\
\hline
\end{tabular}

descriptions. Row totals give the number of barrows from which a particular barrow is readily sighted; column totals subtract from these prior figures those cases within the same cluster of adjacent and, perforce, intervisible barrows. The matrix formalizes observations made by Tilley. Clusters $14-16$ on the western end of the ridge top and 19-21 and 22-23 on the eastern end are particularly salient and form part of one intervisible network that stands apart of Burcombe Spur is 'almost a mirror image of the most southerly barrow (no. 1) on the low spur above Bishopstone'. Apparently not much is to be made of this particular symmetry, although it draws attention to an obvious, but seemingly unnoted, pattern. Burcombe Spur is part of a three-pronged, northward extension of high ground associated with six barrows, including no. 23 , 'the largest and most impressive surviving barrow in the area'. Note that this three-pronged extension has its mirror image in the three-tined, antler-like extension of coombes into the scarp of Hydon Hill, an area associated with eight barrows in two clusters. Seen as a cartographic Rorschach, a southwest-northeast axis cuts diagonally across the Ebble-Nadder ridge. Treating spurs and coombes as topographic artwork, this axis connects a negative design to its positive counterpart. Furthermore, this axis is one of complete inter-site invisibility, unlike barrow clusters on the ridge-top skyline, or the coombe-hugging barrows arranged, according to Tilley, as if they were steps in a process of metamorphosis.

Tilley suggests that dykes, as headward extensions of coombes, are paths rather than fences. Their placement on the Ebble-Nadder supports such an interpretation, and to view linear ditches and embankments as culture copies of erosional coombes is 
a comparison with manual grounding. Yet even this most plausible suggestion can be questioned. Dykes $\mathrm{C}$ and D enclose and, in a sense, shut out 17 of 21 barrows (excluding the outliers 1-3) from the central expanse that dominates the section of the EbbleNadder ridge plotted in Figure 4. The exceptions are the two 'now destroyed' barrows 17-18 and the 'small adjoining barrows' $4-5$ that border Stoke Down. Whatever intentions governed Iron Age dyke construction, closing off, but not obliterating, the dead cannot be excluded.

Monuments have stories to tell, but their main power is to invoke story-telling by others. Now and then, if they would only wink.

Joanna Brück, Department of Archaeology, University College Dublin, Belfield, Dublin 4, Ireland; joanna.bruck@ucd.ie.

Tilley's paper is a welcome addition to the body of literature addressing the relationship between Bronze Age and Iron Age monuments and the landscapes in which they were set. It is especially refreshing to see a phenomenological approach applied to Iron Age dykes which, as the author rightly points out, have generally been interpreted in militaristic or functional terms. There are a number of questions which this article raises, however, and I would like to address these here.

Tilley describes in detail the landscape context of the barrows and dykes of the Ebble-Nadder ridge. For example, he outlines the relationship between each barrow or group of barrows and the surrounding scarps, ridges, coombes and spurs. The views from the monuments are described, and patterns of intervisibility noted. It is difficult, however, to assess the significance of the relationships he identifies. How do we know that a particular barrow was deliberately sited so that it might be visible from one direction but invisible from another, or so that it was just below a ridge rather than on the flat ridge top? Might these relationships have been accidental rather than intentional? This is important, because the associations between monuments and particular landscape features are argued to indicate that the latter were of symbolic significance. Only in the case of coombes is a clear link demonstrated: 46 per cent of the barrows in the study area are shown to be located at the heads of coombes or where several coombes join. It might indeed have been useful here to reference other work which has come to similar conclusions, notably Woodward's research on the links between barrows and coombes in Dorset (2000).

On the basis of the relationships he identifies,
Tilley argues for the cosmological significance of the landscape. Although this is an important point, phenomenological approaches are often guilty of over-emphasizing the symbolic dimensions of landscape without fully considering other aspects. In nonWestern societies, belief systems are not divorced from everyday living but inform and underpin other elements of life, including economic practices. The contrasts and comparisons drawn between different elements of the landscape, for example, are likely to have been used to describe and legitimate social and political differences both within and between communities. Although Tilley touches on this point, I felt that its possible implications could have been discussed more fully.

Finally, it is not clear whether the later prehistoric inhabitants of the Ebble-Nadder ridge would have recognized the series of distinctions Tilley draws between ridge tops and coombes (e.g. exterior/interior, visible/secret), or how they would have judged or evaluated such differences. His argument could perhaps have been made more strongly here. This raises a final important point, that is the extent to which phenomenology can really provide an 'inside' view, as Tilley argues in his introduction. Certainly, this is problematic; in any event, it would be useful to know exactly what the author means by his use of the term 'inside'.

\section{Reply to comments by Christopher Tilley}

I would like to thank Joanna Brück, John Barrett and Warren DeBoer for their constructive and critical comments on my article. All, in one way or another, ask what an 'insider's' knowledge of these monuments might be. John Barrett makes the point that historical knowledge must perforce be the knowledge of an outsider who in some way claims to understand the lives of others. I agree; we can only suggest interpretative possibilities based on contemporary observations and experiences. The fundamental point being made in the article, however, is that by the sensuous exploration of past monuments and landscapes through our bodies at a human scale, rather than the abstracted scale of the map or a series of measurements or plans, we are able to appreciate and understand them in a strikingly different way. We and the people of the past share carnal bodies. By walking, sensing and experiencing through our bodies we directly share at least something with the people of the past. Of course, we see ruins and not half-finished monuments, and the vegetation was different, but the 'bones' of the land, the lines and forms of the coombes and the ridges in the present 
case, were virtually the same in the Bronze and Iron Age past as they are now. Only some metres of erosion and colluvium separate us and them. Through walking and experiencing the landscape we do indeed move from being total outsiders to share at least something in common with prehistoric people, a common sensuous bodily reference point with relation to the landscape. Only to that limited extent can we ever claim to be 'inside' that world. As for the rest, to be inside the 'habitus of bodily disciplines' as Barrett puts it, we can share nothing. We can only interpret from the outside. So the claim being made is very limited but, I feel, is nevertheless very significant: our bodies and our sensuous consciousness can help us as interpretative tools.

Joanna Brück asks whether the relationships between barrow locales might be accidental and not indicative of the kinds of metaphoric relationships between coombes, scarps and ridge tops proposed. In my view barrow locations were never accidental or, as she seems to imply, perhaps chosen at random. De Boer's careful reanalysis of the information provided in the article makes that point strongly enough. What we lack, unfortunately, is any information about temporality, given the lack of excavation evidence. If we knew which barrows were constructed first then the discussion could move on to address directly the question of the significance of barrow intervisibility or invisibility in quite a different manner than is currently possible. As usual we are hampered by the limitations of the evidence available to us.

I agree entirely with Joanna Brück's point that the symbolic dimensions of landscape were part of everyday life, of what she terms 'economic' practices. But to use the term 'economic' at all is surely to suggest an unwarranted divide between meaning and making a living. Going back again to the limitations of the evidence available to us a more interesting point can be made. Compared with the thousands of barrows in the landscape in the Bronze Age, our knowledge of domestic settlements and practices of the period is slight or non-existent. We need to find more creative ways to link the world of barrows erected in relationship to the dead with the worlds of the living; to use, for example, our knowledge of mortuary rituals and symbols to reconstruct the everyday rather than regarding them as two separate domains that might, or might not, have been linked together. In relation to barrow placement in the landscape there is much work to be done beyond simple assumptions about territoriality and genealogical ties. That clearly requires a great deal of rethinking of the manner in which we explore and interpret the past. This leads me directly on to two more points.

If we consider the manner in which prehistory is written, particularly in synthethic works rather than individual excavation or site reports, what we consistently find is a kind of cherry-picking of significant sites, which basically means those which have been excavated, or well excavated, or extensively excavated. The results are then generalized to a region or a landscape or the whole of Britain. Such generalizations, of course, subsume local differences and assume, for example, that Bronze Age mortuary practices and their significance throughout an area such as Wessex were pretty much the same. This may or may not be the case given the limitations of what can be excavated. By conducting detailed studies of barrow locations, from the kind of phenomenological perspective on place outlined in my article, we are able to investigate local, regional and inter-regional similarities and differences in a manner that will never be possible through excavation given the financial, practical and social and political constraints on archaeological practice. In so doing we can hence arrive at a much more nuanced understanding of place and landscape. We need comparative studies and this, I think, might be one future for field archeology, that compared with excavation is both non-destructive and very very cheap: in the case of this article, quite literally, one man and his dog! The fact that Warren De Boer is able critically to reconsider my account and come up with some imaginative interpretations which take it further and in a different direction I find very heartening indeed.

The second point is directly related to the last. The results of field walking, survey and aerial photographic interpretation conducted by the first generations of field archaeologists in Britain have provided us with a treasure trove of information regarding the distribution of ancient monuments and basic information about their morphology, size and other features. The kind of perspective advocated here allows us to move on to make more interpretative sense of the landscape by returning to the field and thinking beyond the monument itself to its relation to others and to the forms of the landscape in which it is found. Even where a monument has been totally destroyed we can still consider its location and make use of poor data in areas such as the EbbleNadder ridge where little or nothing has been excavated and many or most monuments destroyed.

To return to Joanna Brück's point about possible chance in barrow location I want to suggest that the 
landscape provides a series of affordances which can be exploited through choosing one locale rather than another. In the region discussed these were principally the coombes and the character of the ridge tops and scarp slopes. In other areas such as Bodmin Moor in Cornwall (Tilley 1995; 1996) the tors or rock outcrops were of fundamental significance to the way people thought through their worlds. The simple point to be made again about coombes or tors is that one cannot appreciate their importance until one has visited and experienced their powers and effects. Then the significance of barrow location begins to fit into the place and make some sense, inviting the construction of narratives inspired by being in place.

\section{References}

Bradley, R., 1990. The Passage of Arms. Cambridge: Cambridge University Press.

Bradley, R., 2000. An Archaeology of Natural Places. London: Routledge.

Clay, R., 1924. An early Iron Age settlement on Fyfield Bavant Down. Wiltshire Archaeological and Natural History Magazine 42, 457-96.

Clay, R., 1925. An inhabited site of La Tène I date on
Swallowcliffe Down. Wiltshire Archaeological and Natural History Magazine 43, 59-93.

Clay, R., 1927. Some prehistoric ways. Antiquity 1, 54-65.

Colt Hoare, R., 1812. The Ancient History of Wiltshire, vol 1. London: William Miller.

Cunliffe, B., 1990. Before hillforts. Oxford Journal of Archaeology 9, 323-36.

Fowler, P., 1964. Cross ridge dykes on the Ebble-Nadder ridge. Wiltshire Archaeological and Natural History Magazine 59, 46-57.

Spratt, D., 1989. Linear Earthworks of the Tabular Hills, Northeast Yorkshire. Sheffield: University of Sheffield Department of Archaeology and Prehistory.

Sumner, H., 1913. The Ancient Earthworks of Cranborne Chase. London: Chiswick Press.

Tilley, C., 1994. A Phenomenology of Landscape. Oxford: Berg Publishers.

Tilley, C., 1995. Rocks as resources: landscapes and power. Cornish Archaeology 34, 5-57.

Tilley, C., 1996. The powers of rocks: topography and monument construction on Bodmin Moor. World Archaeology 28, 161-76.

Tilley, C., 1999. Metaphor and Material Culture. Oxford: Blackwell

Tilley, C., 2004. The Materiality of Stone: Explorations in Landscape Phenomenology. Oxford: Berg.

Woodward, A., 2000. British Barrows: a Matter of Life and Death. Stroud: Tempus Publishing. 


\section{Studies in Honour of Colin Renfrew}

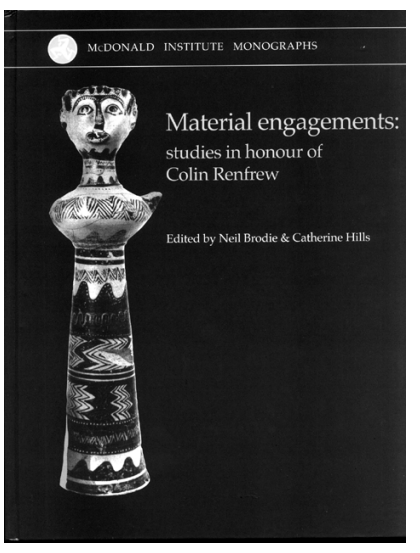

\section{Material Engagements}

edited by Neil Brodie \& Catherine Hills

The subject matter of archaeology is the engagement of human beings, now and in the past, with both the natural world and the material world they have created. All aspects of human activity are potentially relevant to archaeological research, and, conversely, the ways in which others, especially artists and anthropologists, have investigated the world are of interest to archaeologists. Archaeological artefacts and sites are also used by groups and nations to establish identity, and for financial gain, both through tourism and trade in antiquities. Colin Renfrew has actively engaged with art, with politics and with the antiquities trade, and has presented his ideas to broad audiences through accessible books and television programmes, as well as championing the cause of archaeology in many public roles. The papers in this volume, which have been written by colleagues and former students on the occasion of his retirement, relate to all of these subject areas, and together give some idea of the complexity of the issues raised by critical engagements with the material world, both past and present. 180 pp., col. figs. (McDonald Institute Monographs, McDonald Institute 2004) ISBN 1-902937-26-0. Hardback. Price GB £35; US\$70.

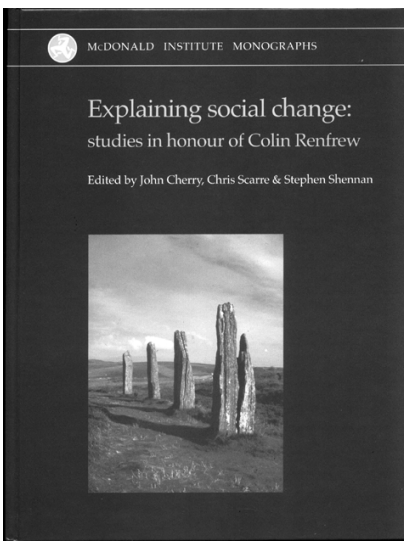

\section{Explaining Social Change}

edited by John Cherry, Chris Scarre \& Stephen Shennan

Over the past 30 years, social archaeology has become one of the central fields of archaeological research, placing human societies at the heart of our understanding of the human past. Colin Renfrew has been a key champion of social archaeology, and the present volume brings together a series of papers on the occasion of his retirement. They have been written by colleagues and former students, and touch upon many of the themes that he himself has studied and about which he has written so persuasively and engagingly: the development of the human mind, trade and exchange, social change, chiefdoms and states, and the archaeology of island societies. These studies focus not on earlier work, however, but reveal the new directions that have developed in recent years, bringing the study of social archaeology firmly into the twenty-first century. 240 pp., b/w figs. (McDonald Institute Monographs, McDonald Institute 2004) ISBN 1-902937-23-6. Hardback. Price GB £35; US\$70.

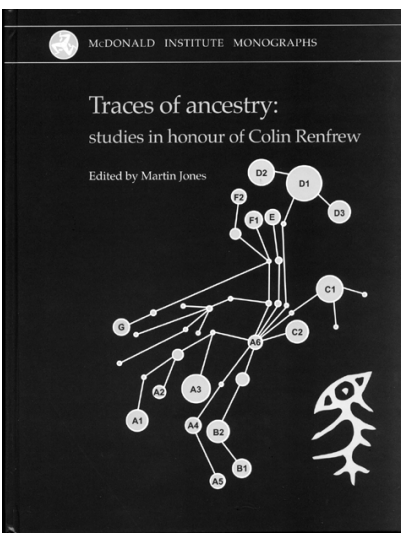

\section{Traces of Ancestry}

edited by Martin Jones

In 1987, Colin Renfrew's Archaeology and Language challenged many perceptions about how one language family spread across large parts of the world. In doing so he reinvigorated an important exchange between archaeologists and historical linguists. At precisely the same time, a quite separate field, human genetics, was making considerable steps forward in the elucidation of human ancestry. These three parallel lines of enquiry into genes, words, and things have, over the ensuing two decades, entirely transformed our perceptions of the human past. This volume brings together contributors to that transformation from around the world, to honour Colin Renfrew with a series of key papers. They include a number of impressive synthetic statements, as well as case studies at the frontiers of three different branches of research. They range from global accounts of human dispersal through to archaeological, genetic and linguistic studies, illustrating what has been achieved over the past two decades, and the most promising avenues of research for the future. 162 pp., b/w figs. (McDonald Institute Monographs, McDonald Institute 2004) ISBN 1-902937-25-2. Hardback. Price GB £30; US\$60.

\section{Buy all three books at the special price of only $£ 75 / \$ 150.00$ !}

To order contact Oxbow Books, Park End Place, Oxford, UK, OX1 1HN; (0)(1865) 241249; (0)(1865) 794449 (FAX); www.oxbowbooks.com 